CONCEPTS AND DATA-COLLECTION TECHNIQUES USED

IN A STUDY OF THE UNSATURATED ZONE AT A

LOW-LEVEL RADIOACTIVE-WASTE DISPOSAL

SITE NEAR SHEFFIELD, ILLINOIS

by R. W. Healy, M. P. deVries, and R. G. Striegl

U.S. GEOLOGICAL SURVEY

Water-Resources Investigations Report 85-4228

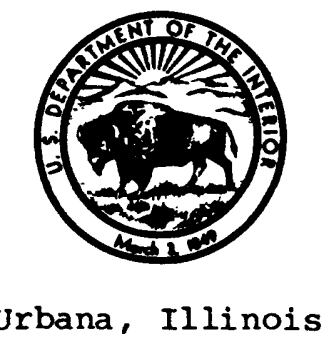

1986 
UNITED STATES DEPARTMENT OF THE INTERIOR

DONALD PAUL HODEL, Secretary

GEOLOGICAL SURVEY

Dallas L. Peck, Director

For additional information, write to:

District Chief U.S. Geological Survey Water Resources Division 102 E. Main St., 4th Floor Urbana, IL 61801
Copies of this report can be purchased from:

Open-File Services Section Western Distribution Branch U.S. Geological Survey Box 25425, Federal Center Denver, CO 80225 
Abstract...........................................1

Introduction ........................................1

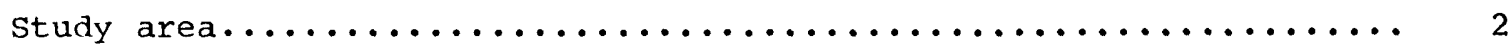

Climate.........................................

Concepts.............................................

Evapotranspiration....................................

Water movement through the unsaturated zone.................. 12

Radionuclide movement through the unsaturated zone............ 15

Data-collection techniques...............................17

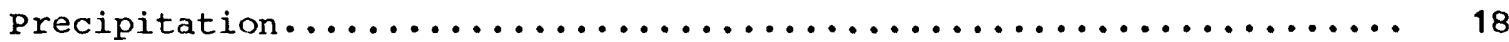

Net radiation.......................................18

Soil-heat flux......................................19

Water-vapor pressure and air temperature..................... 19

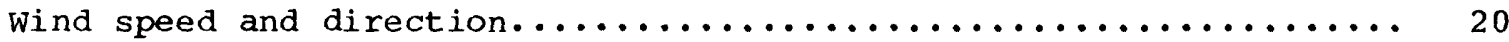

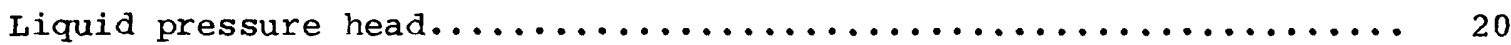

Soil-moisture content............................... 21

Neutron moderation................................ 25

Gamma-ray attenuation............................ 27

Soil-gas pressure..................................... 28

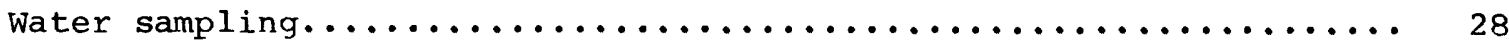

Soil sampling........................................ 29

Gas sampling......................................... 29

Sample handling..................................... 31

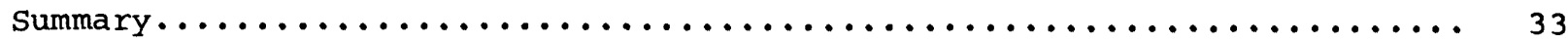

References cited....................................... 
Figure 1. Map showing location of Sheffield low-level radioactivewaste disposal site...........................

2. Topographic map of Sheffield site showing location of

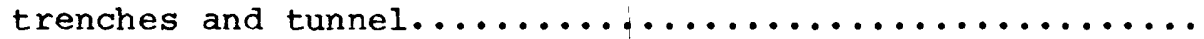

3. Map showing locations of geologic cross sections, lysimeter clusters, soil-gas piezometers, rain gages, meteorological station, and unsaturated-zone study

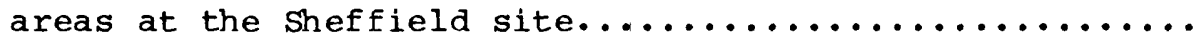

4. Geologic section $C-C^{\prime}$ of Sheffield site.................

5. Graphs showing characteristics of three geologic units present at the Sheffield site: A, Volumetric moisture content vs. 1iquid pressure helad; B, Moisture capacity vs. liquid pressure head; and $c$, Hydraulic conductivity vs. liquid pressure head.......................

6. Schematic diagram of soil-water tensiometer used at

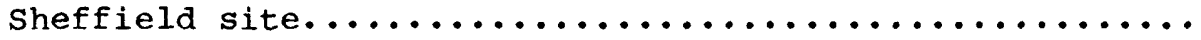

7. Map showing meteorological station and trench-cap study area, instrument locations, and line of section $D-D^{\prime} \ldots . .$.

8. Section $D^{-} D^{\prime}$ showing lithology and instrumentation for observing subsurface moisture movement at a trench cap....

9. Sketch showing configuration of neutron moderation and gamma-ray attenuation soil-moisture probes............

10. Section E-E' showing lithology and locations of soil-gas

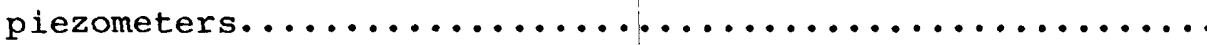

11. Diagram of flow-through system for gas sampling.......... 

or cgs units

\section{Area}

square centimeter $\left(\mathrm{cm}^{2}\right)$

0.1550

square meter $\left(\mathrm{m}^{2}\right)$

square inch $\left(i n^{2}\right)$ square foot $\left(f t^{2}\right)$

\section{Energy}

joule (J)

0.0009478

0.2388

\section{Energy/Area Time}

watt per square meter $\left(w / m^{2}\right)$

0.005290

0.001424

0.1761

watt per square meter

per degree kelvin

$\left(\mathrm{w} / \mathrm{m}^{2} \cdot \circ \mathrm{K}\right)$

\section{Length}

nanometer ( $\mathrm{nm}$ )

micrometer ( $\mu \mathrm{m}$ )

millimeter (mm)

meter (m)

kilometer $(\mathrm{km})$

Mass

Kilogram (kg)

Mass/Volume (Density)

kilogram per cubic meter

$\left(\mathrm{kg} / \mathrm{m}^{3}\right)$

0.06243

0.00003937

0.03937

0.03937

3.281

0.6214

$2 \cdot 205$

Power

watt (W) (Btu/ft $\mathrm{t}^{2} \cdot \mathrm{min}$ )
$3 \cdot 412$

0.2388 pound mass (1 bm)

British thermal unit per square foot per minute

calorie per square centimeter per minute $\left(\mathrm{cal} / \mathrm{Cm}^{2} \cdot \mathrm{min}\right)$

British thermal unit per square foot per hour per degree Fahrenheit

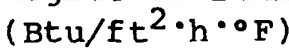

mil

mil

inch (in.)

foot (ft)

mile (mi)

pound per cubic foot $\left(1 \mathrm{~b} / \mathrm{ft} \mathrm{t}^{3}\right)$

British thermal unit per hour $(\mathrm{Btu} / \mathrm{h})$ calories per second (cal/s) 
CONVERSION TABLE--Continued

Multiply metric (SI) Unit

By

To obtain inch-pound or cgs units

Pressure

kilopascal (kPa)

0.2953

10.00

inch of mercury in $(\mathrm{Hg})$ millibar (mb)

Temperature

degree Celsius $\left({ }^{\circ} \mathrm{C}\right)$

$\mathrm{F}=9 / 5^{\circ} \mathrm{C}+32$ degree Fahrenheit $\left({ }^{\circ} \mathrm{F}\right)$

kelvin $(\mathrm{K})$

$(\mathrm{K}-273.15) 1.8+32$ degree Fahrenheit $\left({ }^{\circ} \mathrm{F}\right)$

Velocity

meter per second $(\mathrm{m} / \mathrm{s})$

2.237

mile per hour $(\mathrm{mi} / \mathrm{h})$

Volume

cubic meter $\left(\mathrm{m}^{3}\right)$

0.0008107

acre-foot (acre-ft) 


\title{
CONCEPTS AND DATA-COLLECTION TECHNIQUES USED IN A STUDY \\ OF THE UNSATURATED ZONE AT A LOW-LEVEL RADIOACTIVE- \\ WASTE DISPOSAL SITE NEAR SHEFFIELD, ILLINOIS
}

By R. W. Healy, M. P. deVries, and R. G. Striegl

\begin{abstract}
A study of water and radionuclide movement through the unsaturated zone is being conducted at the low-level radioactive-waste disposal site near Sheffield, Illinois. Included in the study are detailed investigations of evapotranspiration, movement of water through waste-trench covers, and movement of water and radionuclides (dissolved and gaseous) from the trenches.

An energy balance/Bowen ratio approach is used to determine evapotranspiration. Precipitation, net radiation, soil-heat flux, air temperature and water-vapor content gradients, wind speed, and wind direction are measured. Soil-water tension is measured with tensiometers that are connected to pressure transducers. Meteorological sensors and tensiometers are monitored with automatic data loggers. Soil-moisture contents are measured through small-diameter access tubes with neutron and gamma-ray attenuation gages. Data beneath the trenches are obtained through a 130-meter-long tunnel which extends under four of the trenches. Water samples are obtained with suction lysimeters, and samples of the geologic material are obtained with core tubes. These samples are analyzed for radiometric and inorganic chemistry. Gas samples are obtained from gas piezometers and analyzed for partial pressures of major constituents, Radon-222, tritiated water vapor, and carbon-14 dioxide.
\end{abstract}

\section{INTRODUCTION}

The Low-level Radioactive Waste Policy Act, enacted by Congress in 1980, states that by 1986 each state will be responsible for the disposal of lowlevel waste generated within its borders. To comply with the Act, most states are joining in compacts with neighbor states to develop regional disposal sites.

Because only three of the six existing commercial disposal sites are currently active, several new locations must be selected in the near future. The U.S. Geological Survey, although not a regulatory agency, has been directed by Congress to conduct investigations and research aimed at establishing a technical basis upon which earth science criteria can be developed, tested, and enforced by other agencies for the selection and operation of lowlevel disposal sites (Robertson, 1981, p. 22). 
A great deal of research has been done on phenomena related to water and radionuclide movement within porous media, but only a relatively small amount of this work has actually been performed at existing commercial disposal sites within the United States. The work that has been done at these sites has been directed primarily towards studying water and radionuclide movement within the saturated zones (see for example Fischer, 1983, p. 52). Insufficient attention has been paid to water, vapor, and solute movement within the unsaturated zone (Siefken, 1982, p. 1). This project was undertaken to study the movement of water and radionuclides within the unsaturated zone at an existing commercial low-level radioactive-waste disposal site. The project is divided into five major areas of investigation: (1) Evapotranspiration, (2) movement of infiltrated water through a trench cover, (3) water movement throughout the remaining thickness of the unsaturated zone, (4) chemistry of water within the unsaturated zone as it pertains to radionuclide movement, and (5) movement of radionuclides in the gaseous phase. These areas require data-collection techniques and specialized instrumentation which may be unfamiliar to waterresources investigators.

This report presents hydrologic theory and data-collection techniques used to quantify the movement of water and radionuclides within the unsaturated zone at a low-level radioactive-waste disposal site. Included are discussions of logic and methods used for estimating evapotranspiration, for determining rates of water movement in the unsaturated zone, and for sampling pore water and gases within the unsaturated zone. Future reports will present results in each of these areas. Previous studies have been conducted at the site on hydrogeology and ground-water flow (Foster and Erickson, 1980; Foster, Erickson, and Healy, 1984; Foster, Garklavs, and Mackey, 1984). Runoff and sediment transport at the site are currently being studied (Gray, 1984, p. 534 ).

\section{Study Area}

The study site is located on 8.1 hectares (ha) of rolling terrain, 5 kilometers $(\mathrm{km})$ southwest of Sheffield, Illinois (fig. 1). Surface water drains from the site to three intermittent streams that drain to a tributary of Lawson Creek (fig. 2). The site is constructed in unconsolidated glacial and eolian deposits ranging in thickness from 3 to 30 meters (m). Beneath these deposits lie about $140 \mathrm{~m}$ of Pennsylvanian rock which is composed of shale, siltstone, and coal. Regional aquifers, contained in silurian and ordovician limestones and dolomites and in Cambrian sandstones, underlie the Pennsylvanian rock. The Pennsylvanian shale effectively isolates the waste trenches from these aquifers. Ground water moving beneath the site, within the glacial deposits, discharges to a strip-mine lake $0.5 \mathrm{~km}$ northeast of the site. This ground-water movement occurs primarily within a sand unit (Toulon Member of the Glasford Formation as used by the Illinois State Geological Survey) which underlies two-thirds of the site (Foster, Erickson, and Healy, 1984, p. 23). Virtually all water within the saturated zone is derived from local precipitation. The saturated zone within the unconsolidated deposits has an average thickness of $6.1 \mathrm{~m}$, while the unsaturated zone has an average thickness of $12.2 \mathrm{~m}$. 


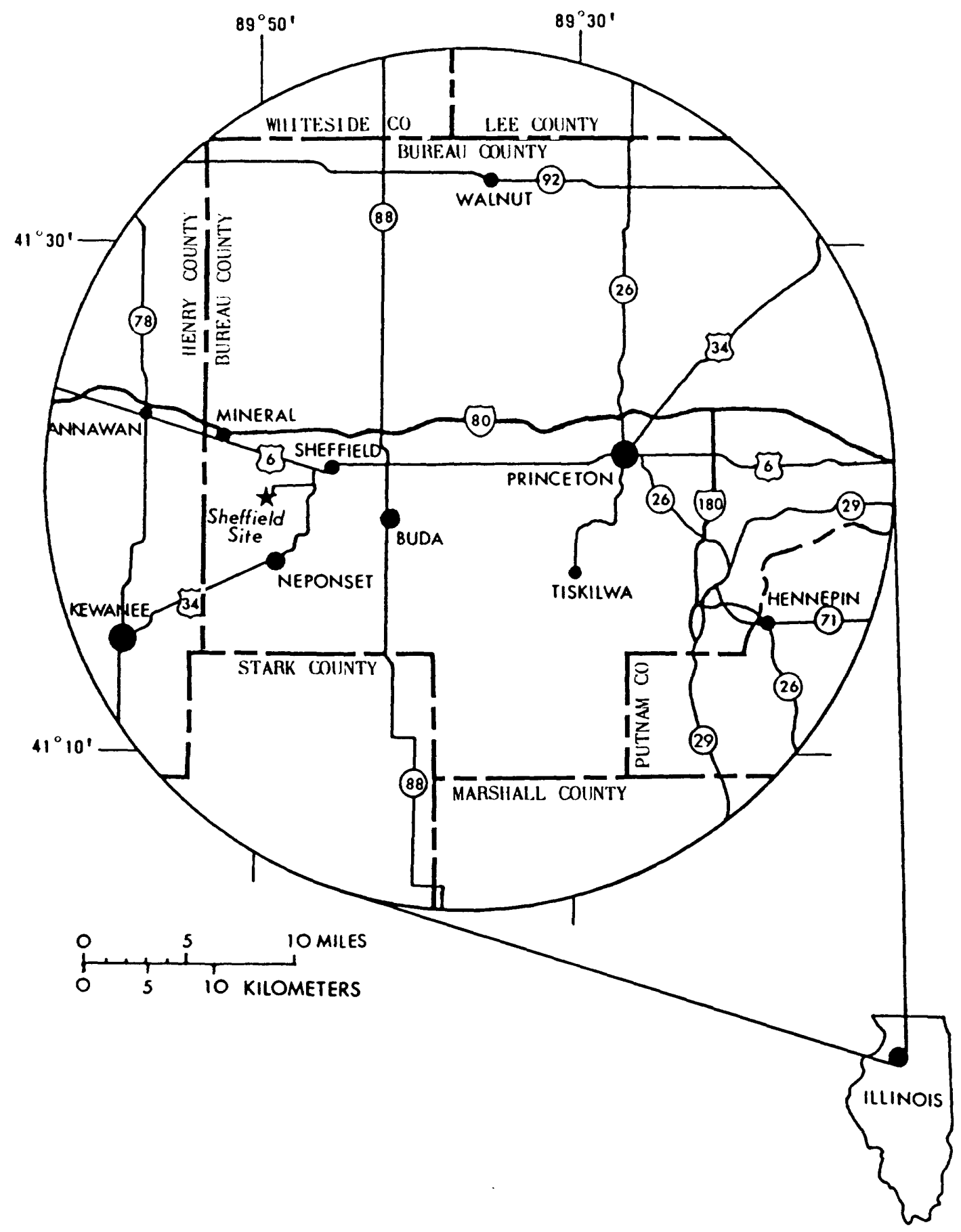

Figure 1.--Location of Sheffield low-level radioactive-waste disposal site. 


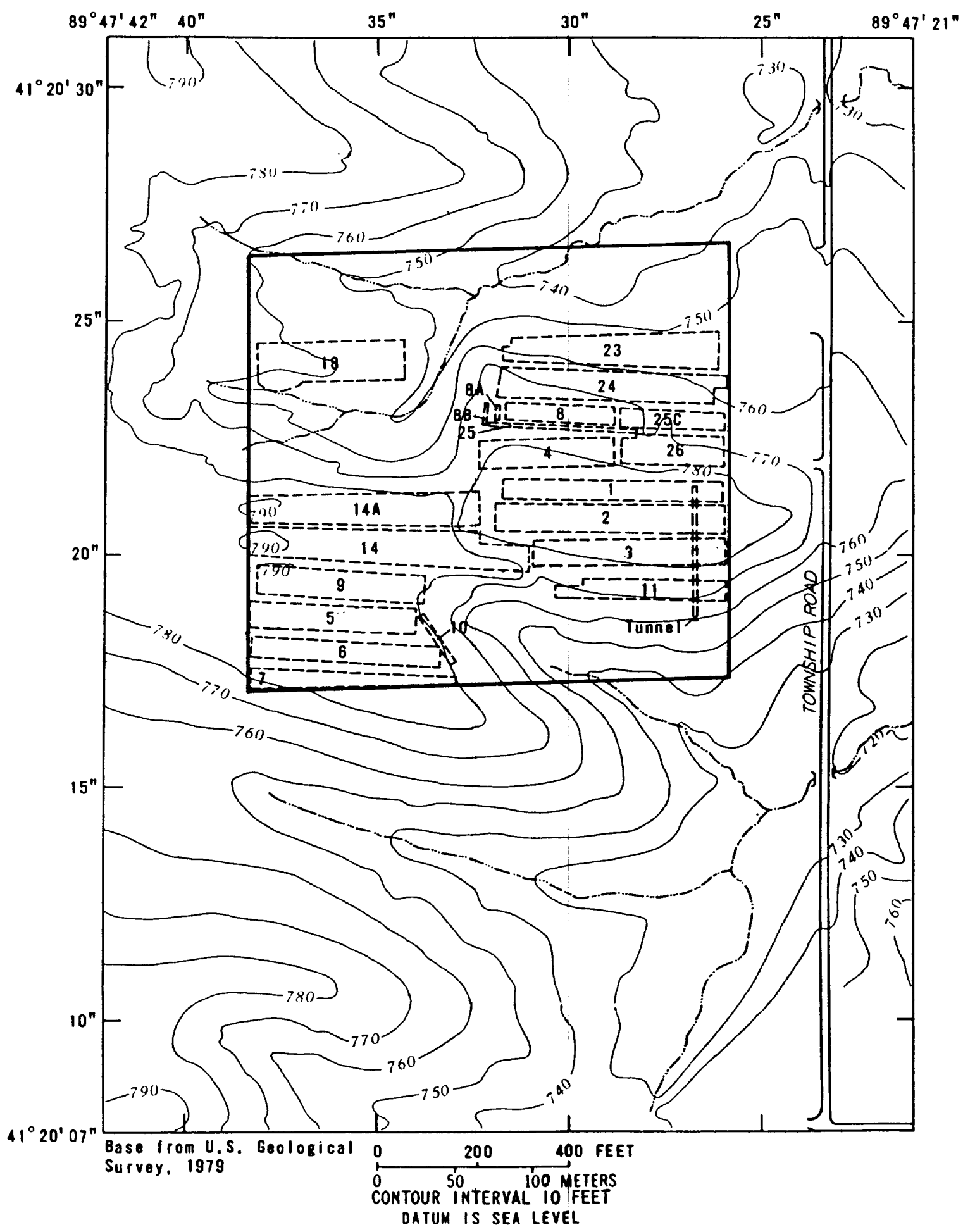

EXPLANATION

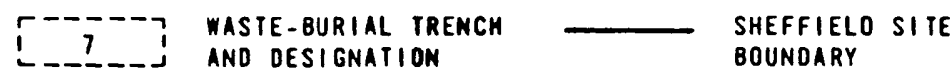

Figure 2.--Topographic map of Sheffield site showing location of trenches and tunnel. 
Eight distinct stratigraphic units have been identified within the glacial deposits, all of which are present within the unsaturated zone (Foster and Erickson, 1980; Foster, Erickson, and Healy, 1984). These units vary in lithology from silty clay, to silt, to sand and gravel. The areal extent of each of the units is also highly variable. The complex layering of some of these units is illustrated by a cross-sectional view through the site (figs. 3 and 4). Surficial material consists of Modern Soil, which is developed in the upper part of the Peoria Loess and is primarily a clayey silt, and fill, which consists of clayey silt to silt. Fill material has been used to build trench caps and to raise land surface in low areas.

Radioactive wastes were buried at the site from August 1967 to April 1978, during which time 21 trenches ( $f i g .2)$ were filled with about 300,000 cubic meters $\left(\mathrm{m}^{3}\right)$ of material. The total activity of the waste was about 60,000 curies and included 13.6 kilograms $(\mathrm{kg})$ plutonium-239, 1.7 grams $(\mathrm{g})$ uranium-233, $40.7 \mathrm{~kg}$ uranium-235, and $270,845 \mathrm{~kg}$ of source material (Illinois Department of Nuclear safety, written commun., 1979).

Nineteen of the trenches were dug in undisturbed material, and two trenches were elevated above the existing land surface by constructing walls of compacted clayey silt. Waste was randomly placed in trenches and covered with about $0.25 \mathrm{~m}$ of compacted clayey silt, on which fill material was mounded lengthwise. Thickness of the mounds varies from about $1.5 \mathrm{~m}$ at the center to about $0.5 \mathrm{~m}$ at the edges. Placement of trenches adjacent to each other has resulted in small valleys between mounds, which channel surface runoff. Trench caps have been smoothly contoured and seeded with herbaceous vegetation, primarily brome grass (Bromus inermis) and red clover (Trifolium pratense).

The exact content of each burial trench is unknown. Although inventories were kept of the wastes disposed in each trench, they are descriptively poor and quantitatively inaccurate (Kahle and Rowlands, 1981). The buried wastes include such items as resins, the carcasses of laboratory animals, sorbed liquids, glassware, building materials, clothing, containerized gases, paper, and cleanup materials (Foster, Erickson, and Healy, 1984). Containment vessels for these materials include steel drums, wooden crates, plastic containers, concrete casks, and cardboard cartons.

\section{Climate}

The climate in northwestern Illinois is continental, with warm summers and cold winters (State of Illinois, 1958). The mean annual temperature is $10.3^{\circ} \mathrm{C}$. January is usually the coldest month, and July is usually the warmest. The mean annual precipitation is 900 millimeters ( $\mathrm{mm}$ ) based on 43 years of record (U.S. Department of Commerce, 1939-82) from nearby weather stations at Kewanee and Hennepin, Ill. (fig. 1). The maximum annual precipitation for the period of record is $1,330 \mathrm{~mm}$ and the minimum is $650 \mathrm{~mm}$. Late fall and winter are usually the driest periods with precipitation averaging $50 \mathrm{~mm}$ per month for November through March. Spring and early summer are the wettest, with precipitation averaging $80 \mathrm{~mm}$ per month for April through July. Severe convective rainstorms are common during this period (Huff, 1979). 


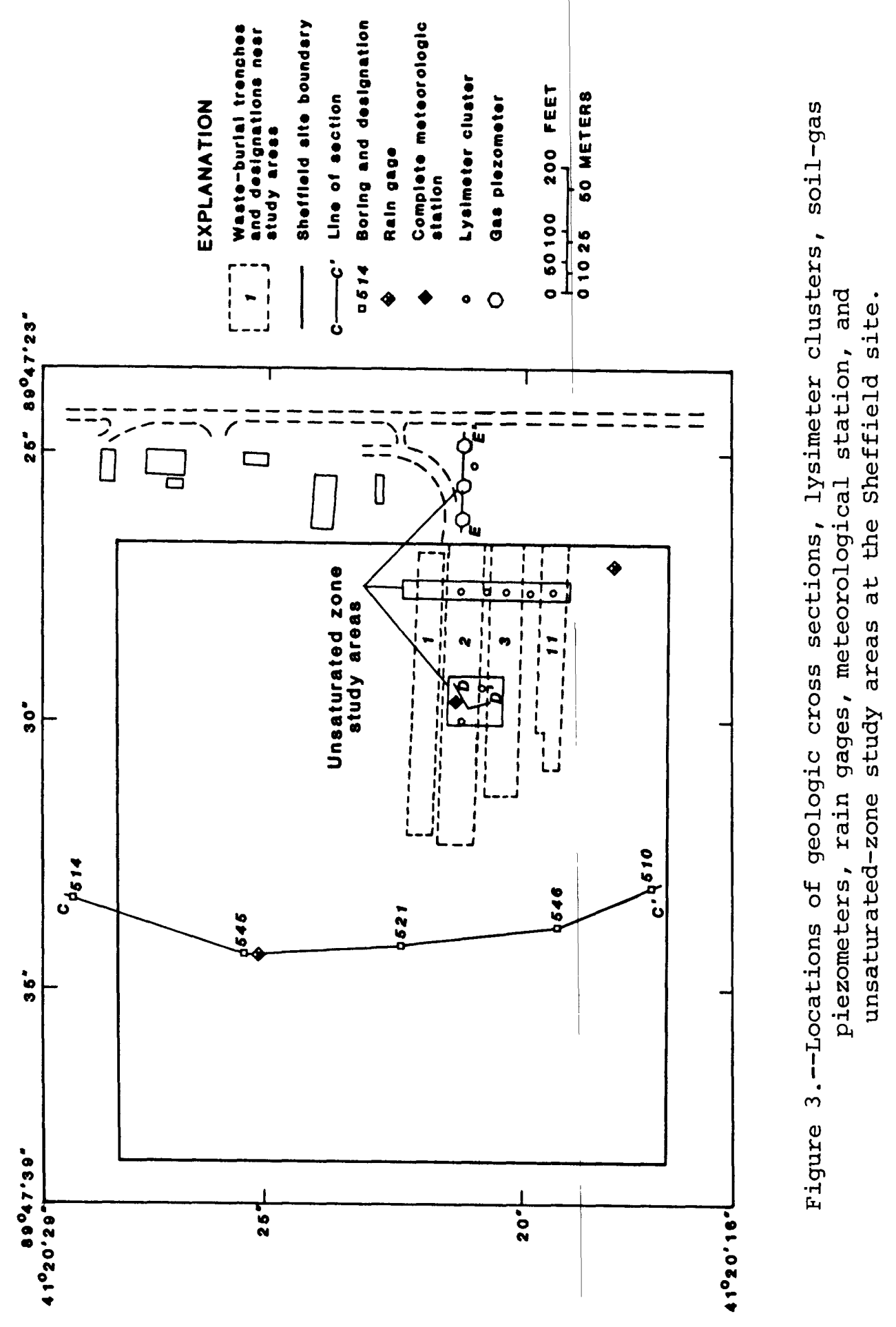




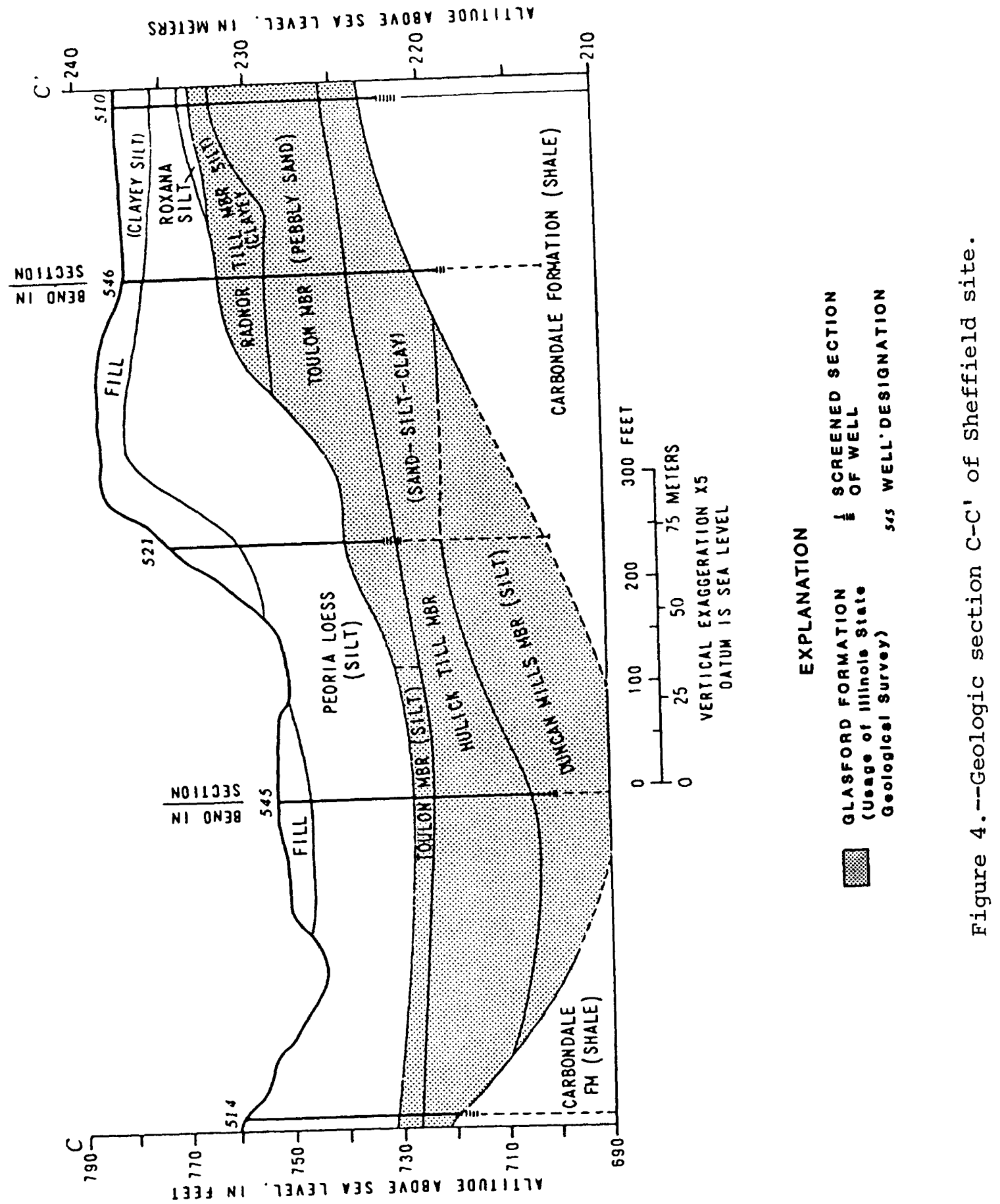


Evapotranspiration is the exchange of water between the soil and the overlying atmosphere. It is an integral part of the hydrologic budget as most precipitation in Illinois is eventually evapotranspired. Jones (1966, p. 12) estimated that, in northern Illinois, annual evapotranspiration averages about 635 to $760 \mathrm{~mm}$. In this study, an energy balance/Bowen ratio approach is used to estimate evapotranspiration.

Water movement through the trench covers is being investigated in an attempt to define the amount, timing, and location of water movement into the trenches. Studying the movement of infiltrated water during and immediately following precipitation requires data collection at a relatively rapid rate as wetting fronts can move quickly through the soil zone. Data from vertical clusters of soil-water tensiometers located within and adjacent to a wastetrench cover are automatically recorded with pressure transducers and data loggers.

The study of water movement through the unsaturated zone is complicated not only by an inability to place instruments within the trenches but also by the complex layering of the different sediments. A 130-m-long tunnel was constructed beneath four of the waste trenches to facilitate data collection.

The study of water chemistry within the unsaturated zone is aimed at defining chemistry of the pore water, identifying the reactions that are occurring naturally within the unsaturated zone, and determining the effects of the buried waste upon these reactions. Samples of water and sediments are obtained from the trench covers and from beneath trenches, as well as from a control area outside the trench area.

The study of gaseous radionuclides within the unsaturated zone is designed to define the spatial and temperal distributions of radon-222 $\left({ }^{222} \mathrm{Rn}\right)$, tritiated water vapor $(\mathrm{HTO}(\mathrm{g}))$, and carbon-14 dioxide $\left({ }^{14} \mathrm{CO}_{2}\right)$. Fluxes of these gases through the unsaturated zone and into the atmosphere can then be estimated. Gas samples are obtained at various depths and distances from a waste trench.

\section{Evapotranspiration}

There are several approaches to determining evapotranspiration rates. Evapotranspiration can be measured directly by monitoring precipitation and the changes in soil-moisture contents, either by repeated soil sampling or with the use of a weighing lysimeter or soil-moisture probe. Evapotranspiration can also be determined as the residual in an energy-balance equation. The Bowen-ratio method (Bowen, 1926) is probably the most widely used of the energy-balance methods. Other methods of determining evapotranspiration, such as eddy-correlation and aerodynamic-profile, are based on the upward transfer of mass in the atmosphere. 
The energy balance approach, using the Bowen-ratio method, is being used at the Sheffield site as the primary method to determine evapotranspiration. The aerodynamic-profile method is being used as a secondary method. The energy balance states that the energy arriving at the Earth's surface goes into heating the air (sensible heat), heating soil, and evapotranspiring available water (latent heat). The energy-balance equation can be written as

$$
R_{n}-(H+L \cdot E+S)=0
$$

where $R_{n}$ is net radiation, in watts per square meter;

$H$ is the sensible heat flux, in watts per square meter;

$L \cdot E$ is the latent heat flux, in watts per square meter;

$L$ is the latent heat of vaporization, in joules per kilogram;

$\mathrm{E}$ is the evapotranspiration rate, in kilograms per square meter per second; and

$S$ is soil heat flux, in watts per square meter.

A few observations regarding assumptions used in developing equation 1 are in order. Fluxes are assumed to be vertical; horizontal fluxes are considered to be negligible. Energy absorbed by photosynthesis and energy stored within the plant canopy are ignored. Fluxes are also assumed to occur at the soil or plant canopy surface. However, it is not possible to measure these fluxes at the surface; measurements are actually made at some finite distance from the surface, and over this distance there will possibly be some flux divergence. Finally, extrapolation of evapotranspiration rates over the entire study area requires that homogeneous conditions exist throughout. This appears to be reasonably valid at the Sheffield site. Although there is some rolling terrain, soil and vegetative cover are very uniform. Bowen (1926) proposed solving the energy-balance equation, using the ratio of sensible- to latent-heat fluxes

$$
\beta=\frac{H}{L \cdot E}=\frac{\rho \cdot C_{p} \cdot K_{h} \cdot \frac{\partial T}{\partial z}}{\rho \cdot L \cdot \frac{\varepsilon}{B} \cdot K_{w} \cdot \frac{\partial e}{\partial z}}
$$

where $\quad B$ is the Bowen ratio (dimensionless);

$\rho$ is the density of the air, in kilograms per cubic meter;

$C_{p}$ is specific heat of dry air at constant pressure, in joules per cubic meter per degree Celsius;

$\partial \mathrm{T} / \partial \mathrm{z}$ is vertical gradient of air temperature, in degrees celsius per meter;

$\partial e / \partial z$ is vertical gradient of water-vapor pressure, in pascals per meter; 
$\varepsilon$ is the ratio of the mole weight of water vapor to dry air (dimensionless), taken to be 0.622 ;

$\mathrm{K}_{\mathrm{h}}$ is the eddy diffusivity for heat, in square meters per second;

$\mathrm{K}_{\mathrm{w}}$ is the eddy diffusivity for water vapor, in square meters per second; and

$B$ is the absolute pressure, in pascals.

In computing $B$, it is usually assumed that $\left(K_{h} / K_{w}\right)=1$ (Denmead and McIlroy, 1970; Swinbank and Dyer, 1967), which simplifies data requirements.

Substituting equation 2 into equation 1 gives

$$
L \cdot E=\frac{\left(R_{n}-S\right)}{1+\beta} \text {. }
$$

The required information, then, is net radiation, soil-heat flux, and vertical gradients of air temperature and water vapor pressure.

Net radiant energy, $R_{n}$, is the net gain of both solar and thermal radiation that the surface receives. It is the driving force for all surface and atmospheric heat and evaporative fluxes. The general equation for net radiant energy is (Munn, 1966, p. 3)

$$
R_{n}=I S-O S+I L-O L
$$

where Is is incoming shortwave radiation/from the Sun, in watts per square meter;

OS is outgoing shortwave radiation reflected from the Earth, in watts per square meter;

IL is incoming longwave radiation from the atmosphere, in watts per square meter; and

or is outgoing longwave radiation emitted from the Earth, in watts per square meter.

Shortwave or solar radiation originates at the Sun and has a wavelength of 0.3 to 3 micrometers ( $\mu \mathrm{m}$ ) (Monteith, 1973, p. 23). Incoming solar radiation is composed of both direct and diffuse radiation. Some of the incoming solar radiation is reflected back into the atmosphere from the Earth. The ratio of reflected to incoming shortwave radiation is termed the surface albedo. values of albedo depend primarily upon the color of the surface: High for light colors and low for dark colors. Typical values are 0.24 for grass, 0.32 for light colored dry soil, 0.05 for open water, and 0.85 for fresh snow (Campbell, 1977, p. 54).

Longwave or thermal radiation is continually emitted by the Earth. Its wavelength ranges from 3 to $100 \mu \mathrm{m}$, with maxiumum energy occurring at a wavelength of about $10 \mu \mathrm{m}$ (Monteith, 1973, p. 23). Instruments measuring thermal 
radiation absorb wavelengths between 4 and $50 \mu \mathrm{m}$. This band width incorporates most of the thermal energy. At least 70 percent of this terrestrial radiation is absorbed by water vapor, ozone, carbon dioxide, and oxygen in the atmosphere (Koberg, 1964). Following Kirchoff's law, these molecules re-emit the radiation in all directions as strongly as they absorb it. The fraction that returns to the Earth's surface is referred to as incoming longwave radiation.

Values of net radiation vary diurnally: Positive during daylight hours and slightly negative at night. Maximum values are obtained around solar noon when solar radiation is greatest. Solar radiation is zero during the night; hence, negative values of net radiation occur because more longwave radiation is being emitted from the Earth's surface than is being returned from the atmosphere.

Heat transfer through soils occurs primarily by the mechanism of internal conduction (Hillel, 1980, p. 289). This involves the exchange of kinetic energy at the molecular level. Heat transfer may also occur by convection and latent-heat transfer. Convection is the process of heat transfer by a liquid or gas flowing through a hotter or cooler body and results in a temperature change of both bodies. The interstitial movement of water or air of a temperature different than the soil, such as the infiltration of cool rain on a warm summer day, results in convective heat flow. Transfer of latent heat consists of the evaporation and condensation of water within soils. Heat is absorbed when water is evaporated, and released upon condensation.

As applied to soil-heat flux, Fourier's first law of heat conduction states that heat flow through soils is in the direction of and proportional to the temperature gradient:

$$
Q=-K \frac{\partial T}{\partial z}
$$

where $Q$ is the heat flow by conduction, in watts per square meter;

$\partial T / \partial z$ is the change in temperature with respect to depth, in degrees Celsius per meter; and

$\mathrm{K}$ is the thermal conductivity, in watts per meter per degree Celsius.

By convention, downward heat flow is positive.

The thermal conductivity of soils can be quite variable and is dependent upon soil characteristics and moisture content. Kersten (1949) presents equations for estimating thermal conductivity based upon texture, density, and moisture content for both frozen and unfrozen soils. Munn (1966, p. 34) states that thermal conductivity can range from 0.167 watts per meter per degree Celsius $\left(\mathrm{W} \mathrm{m}^{-1}{ }^{\circ} \mathrm{C}^{-1}\right.$ ) for dry soils up to $3.34 \mathrm{~W} \mathrm{~m}^{-1} \cdot{ }^{\circ} \mathrm{C}^{-1}$ for wet soils. 
Soil heat flux generally follows a diurnal trend, positive during daylight hours when the soil is being heated by the Sun and negative during the night when the soil is cooling off. Seasonal trends are identical to those of air temperature: Increasing in spring and decreasing in fall. The average annual soil heat flux is very close to zero (Sellers, 1965, p. 101).

A negative air-temperature gradient (that is, temperatures decrease with increasing height) corresponds to a positive sensible heat flux. This condition usually exists during hours of peak net radiation. A positive gradient is referred to as a temperature inversion. Inversions are common at night and can occur occasionally during daylight hours as the result of a strong warm wind. In Arizona, van Hylckama (1980, p. 23) consistently noted positive temperature gradients from early evening through midmorning.

Evapotranspiration ( $L \cdot E$ greater than 0 ) occurs only when the gradient of water-vapor pressure is negative. This gradient is expected to be always negative during daylight hours when net radiation is positive. At nighttime the vapor-pressure gradient may be either negative or positive. A nighttime negative gradient indicates that evapotranspiration is occurring; hence, by the energy-balance equation, there must be a negative sensible-heat flux or soil-heat flux. A positive vapor-pressure gradient, on the other hand, would indicate condensation at the surface. In either case, the magnitude of nighttime fluxes is much less than those occurring during daylight hours.

Wind is an important requirement for evapotranspiration. Without wind the atmospheric boundary layer would reach saturation and evapotranspiration would cease. Atmospheric mixing caused by convection and surface friction results in turbulent mixing by eddies. Although wind speed is not incorporated in the Bowen-ratio method, it is an integral part of aerodynamic-profile methods.

\section{Water Movement through the Unsaturated zone}

Water, from precipitation, which infiltrates is either stored in the soil or moves downward toward the saturated zone. Moisture that is stored near land surface is subsequently available for evaporation and transpiration. water movement within the unsaturated zone is described by the modified Richards equation (Freeze and Cherry, 1979, p. 67)

$$
C\left(h_{p}\right) \frac{\partial h}{\partial t}=\nabla\left(K\left(h_{p}\right) \nabla h\right)+\text { source/sink terms }
$$

where $h$ is total hydraulic head, in meters;

$h_{p}$ is liquid pressure head, in meters;

$t$ is time, in seconds; $c\left(h_{p}\right)$ is specific moisture capacity - a function of $h_{p^{\prime}}$ in inverse

$\mathrm{K}\left(\mathrm{h}_{\mathrm{p}}\right)$ is hydraulic conductivity - a function of $h_{p^{\prime}}$, in meters per second; and 
$\nabla$ is the divergence:

$$
\nabla\left(K\left(h_{p}\right) \nabla h\right)=\frac{\partial}{\partial x}\left(K\left(h_{p}\right) \frac{\partial h}{\partial x}\right)+\frac{\partial}{\partial y}\left(K\left(h_{p}\right) \frac{\partial h}{\partial y}\right)+\frac{\partial}{\partial z}\left(K\left(h_{p}\right) \frac{\partial h}{\partial z}\right)
$$

Total hydraulic head can be written

$$
\mathrm{h}=\mathrm{h}_{\mathrm{p}}+\mathrm{h}_{\mathrm{z}}
$$

where $h_{p}$ is pressure head of the liquid phase which is greater than or equal to zero (assuming atmospheric pressure is zero) for saturated conditions and less than zero in the unsaturated zone. Within the unsaturated zone, $h_{p}$ is sometimes referred to as soilwater tension, soil suction, or matric potential, in meters; and

$h_{z}$ is elevation potential, in meters.

The amount of water contained in a volume of soil is a function of $h_{p}$. As $h_{p}$ becomes more negative, less water is retained in the soil. The plot of volumetric moisture content, $\theta\left(h_{p}\right)$, versus $h_{p}$ is called the moisture-retention curve. Typical moisture-retention curves of geologic materials from the Sheffield site are shown in figure $5 \mathrm{a}$. The shape of the curves is heavily dependent upon the pore-size distribution of the material, as water is drained more easily from the larger pores than from the smaller ones.

It should be noted that the curves in figure $5 a$ are simplifications of the true relation between $\theta$ and $h_{p}$. They represent the main drying curves. The actual relation between $\theta$ and $h_{p}$ is hysteretic; not only is $\theta$ a function of $h_{p}$, but it is also dependent upon whether $h_{p}$ is decreasing or increasing, that is, whether the material is wetting or drying. Moisture-retention curves are generally determined in a soils lab with the use of Tempe cells and pressure plate apparatus (Bouma and others, 1974, p. 22), but may be determined in the field by measuring both the soil-water tension and soil-water content.

Jecific moisture capacity is the amount of change in volumetric moisture content per unit change in $h_{p}$, or the slope of the moisture-retention curve:

$$
C\left(h_{p}\right)=\frac{d \theta\left(h_{p}\right)}{d h_{p}} .
$$

Figure 5b shows plots of specific moisture capacity for the moisture retention curves in figure $5 a$.

Hydraulic conductivity is the volume of water transported through a unit area per unit head gradient per unit time at some fixed value of $h_{p}$. Hydraulic conductivity is determined using one of two approaches: (1) Empirical measurements in the lab or field, or (2) theoretical models based upon the moistureretention curve and the saturated hydraulic conductivity. Empirical techniques are well summarized by Klute (1972), with additional work being done by Arya and others (1975) and Hillel and others (1972). Theoretical models have been 


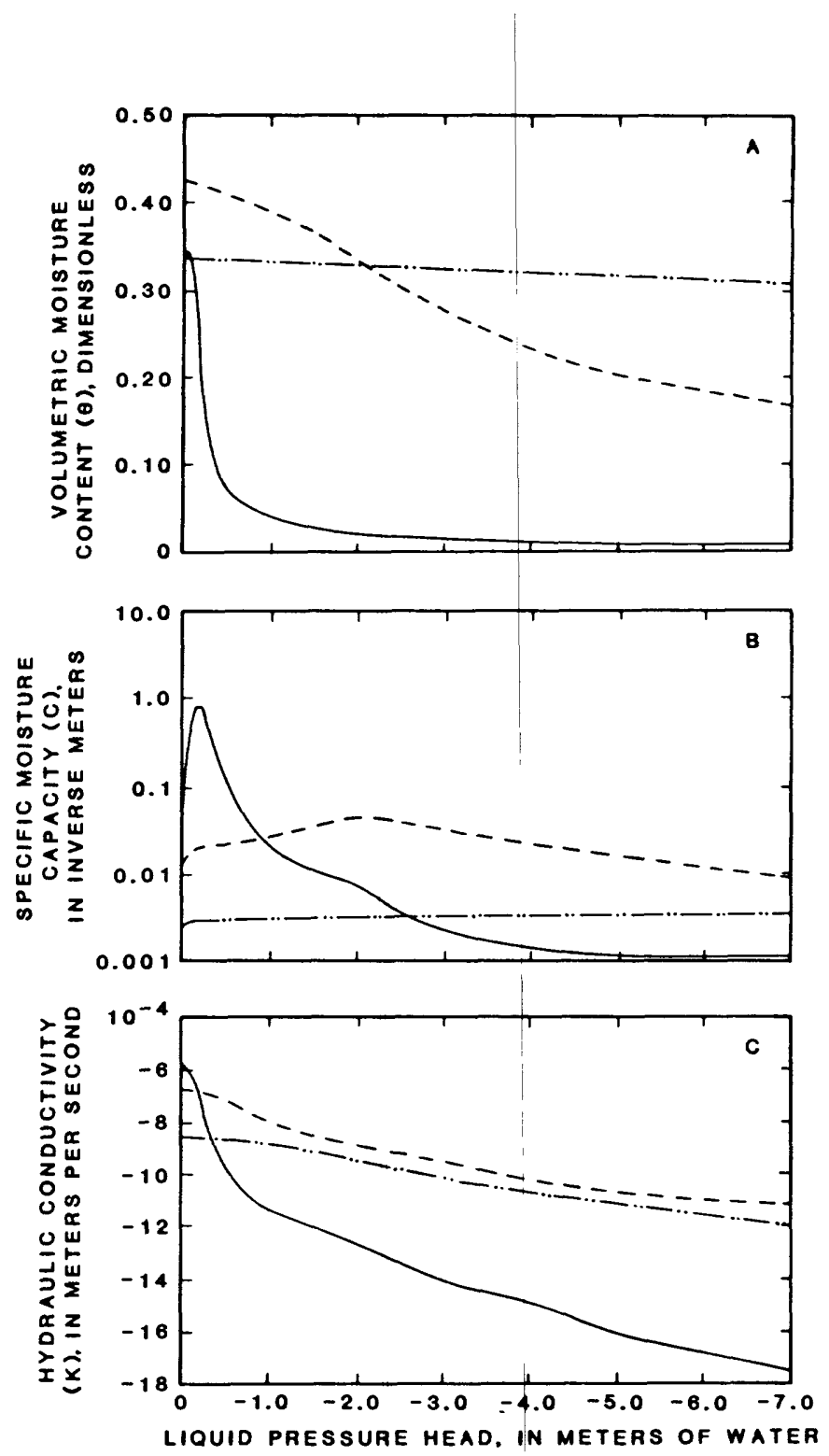

\section{EXPLANATION}
TOULON MBR (PEBBLY SAND)
GLASFORD FORMATION
HULICK TILL MBR (SAND-SILT-CLAY) $\}$ GEOLOGICAL SURVEY)
PEORIA LOESS (SILT)

Figure 5.--Characteristics of three geologic units present at the Sheffield site: A, Volumetric moisture content vs. liquid pressure head; B, Moisture capacity vs. liquid pressure head; $C$, Hydraulic conductivity vs. liquid pressure head. 
proposed by Childs and Collis-George (1950), Marshall (1958), Millington and Quirk (1961), Brooks and Corey (1964), Green and Corey (1971), Jackson and others (1965), and Mualem (1976, 1978). Empirical methods may be more accurate but are often quite complex and subject to measurement error (Ragab and others, 1981). Theoretical methods, on the other hand, are relatively easy to use and are being used for this study. Figure $5 c$ shows curves of $k\left(h_{p}\right)$ versus $h_{p}$ as determined using the method of Green and Corey (1971).

The high degree of nonlinearity of $\theta\left(h_{p}\right), C\left(h_{p}\right)$, and $K\left(h_{p}\right)$ as depicted in figure 5 as well as the high degree of variability among different lithologies illustrates the complex nature of water movement through the unsaturated zone.

Although water movement is primarly downward due to gravity, the variety of different geologic units causes the rate of movement to vary substantially throughout the thickness and areal extent of the unsaturated zone. The manner in which the units are layered may also affect flow rates. Sloping interfaces between materials which have very different physical properties can be preferential pathways, adding a horizontal component to the water movement. Foster, Erickson, and Healy (1984) describe this phenomena in more detail. An understanding of water movement through the unsaturated zone, therefore, requires an accurate definition of the geology, representations of $\theta\left(h_{p}\right), c\left(h_{p}\right)$, and $\mathrm{K}\left(\mathrm{h}_{\mathrm{p}}\right)$ for each different unit, as well as measurements of soil-water tension and content throughout the unsaturated zone.

Although ignored in many studies, the soil-gas pressure can play an important role in infiltration and the subsequent movement of infiltrated water (Morel-seytoux, 1983). By occupying pore space, and not being able to escape, gas can retard the movement of water. Changes in soil-gas pressure may occur as a result of barometric pressure changes, rising or falling water table, or the downward movement of a wetting front. Measurement of soil-gas pressures is usually important only near land surface.

\section{Radionuclide Movement through the Unsaturated zone}

Once radionuclides are released from their containers, they can become dissolved in water moving through the trenches. Some radionuclides can also move as gases. The rate of dissolution is dependent upon several factors including the specific ion and its form, the chemistry of the pore water and gas, the chemistry of the geologic material, and the rate of water movement through the waste. The mobility of radionuclides is also affected by the possible adsorption by soil particles and organic compounds. Tritium $\left({ }^{3} \mathrm{H}\right)$ is the only radionuclide which has been detected in concentrations above background levels (about 200 picocuries per liter [pCi/L]) in ground water at the site (Foster, Erickson, and Healy, 1984). Because tritium is an isotope of hydrogen, it can become incorporated into water molecules and, therefore, move as water.

Movement of dissolved radionulides is described by the advection dispersion equation (simplified from Freeze and Cherry, 1979, p. 402):

$$
\frac{\partial \theta C}{\partial t}=\nabla(\theta D \nabla C)+\nabla(v C)+\lambda \theta C+\delta
$$


where $\mathrm{C}$ is concentration of a constituent, in grams per cubic meter;

$D$ is coefficient of dispersion, in square meters per second;

$v$ is velocity of water, in meters per second;

$\lambda$ is radioactive decay constant, per second;

$\theta$ is volumetric moisture content, in cubic meters per cubic meter; and

$\delta$ is source/sink term, in grams per second.

In general terms, this equation states that the change over time in the amount of a particular constituent at a particular location is dependent upon the rate at which the constituent disperses through the medium, the rate at which water moves through the medium, the rate of radioactive decay, and the rate at which the constituent is added to or removed from the system. Dispersion actually refers to two separate phenomena--hydrodynamic dispersion, which is mixing caused by water movement, and diffusion, which is the molecular movement of the constituent resulting from concentration gradients. Bear (1972, p. 59) discusses in detail the physical meaning of dispersion, as well as theoretical techniques for estimating values of the dispersion coefficient.

The source/sink term, $\delta$, in equation 7 dan include not only the sources of contaminants within the waste trenches, but also chemical reactions that may occur between a constituent and the geologic material and between constituents themselves. Freeze and Cherry (1979, p. 402) state that these reactions can be grouped into six categories: Adsorption-desorption reactions, acid-base reactions, solution-precipitation reactions, oxidation-reduction reactions, ion pairing or complexation, and microbial cell synthesis.

Water movement may be the dominant transport mechanism. As discussed above, it is quite difficult to accurately define the rate of water movement throughout the unsaturated zone. Hence, it is also quite difficult to accurately define the flux rate of constituents. Another complicating factor is the variability, in terms of type, container, and concentration, of the waste within the trenches. This point is illustrated by tritium concentrations encountered during tunnel construction. The concentrations found in pore water differed dramatically with respect to location. Beneath one trench, tritium concentrations were less than $5,000 \mathrm{pCi} / \mathrm{L}$, while beneath another trench they ranged up to 2,500,000 pCi/L (Foster, Erickson, and Healy, 1984).

Radionuclides also move in the gas phase within the unsaturated zone. Containerized gases have been buried at the site, and additional gases may be formed by bacterial dissimilation of the waste and radioactive decay. Transport of gases in the unsaturated zone is primarily controlled by molecular diffusion, although convective flow and thermal diffusion may also be important (Hillel, 1980). Neglecting convection, equation 7 can be modified to describe diffusive movement of gases within the unsaturated zone:

$$
\frac{\partial \theta_{D} C}{\partial t}=\nabla\left(\tau \theta_{D} D_{A B} \nabla C\right)+\lambda \theta_{D} C+\delta
$$


where $\theta_{D}$ is drained porosity, which is the total porosity minus the moisture content (dimensionless);

$\tau$ is tortuosity, which accounts for the increased path length of molecular movement due to the structure of the medium (dimensionless);

$D_{A B}$ is coefficient of diffusion of gas $A$ into gas $B$, in square meters per second; and

other variables are defined as in equation 7.

Concentrations of constituents in solution, in the gas phase, and absorbed to the geologic material, in addition to water velocities, must be known at different locations and at different times to be able to solve equations 7 and 8. Velocities are determined as described above. Samples of water (and geologic material) are obtained from several locations above and below trenches for radionuclide analyses. Water samples are also obtained at five different depths, ranging from 2 to $12 \mathrm{~m}$, at a control site located away from the trenches (fig. 3). Comparison of the inorganic and radiometric chemistry of water on-site and off-site gives some indication of the effect of the trenches. Soil-gas samples are obtained from gas piezometers at various depths and horizontal distances along a line perpendicular to trench 2 (fig. 3). Gas analyses indicate changes in gas chemistry with respect to distance from the trench.

\section{DATA-COLLECTION TECHNIQUES}

Meteorological data are collected for calculation of evapotranspiration. The rate of evapotranspiration is assumed to be uniform over the entire site, so it is important to make the required observations at a representative location. Meteorological instruments are located near the center of the site (fig. 3) for good exposure to wind and solar radiation.

Soil-water tensions, soil-moisture contents, and soil-gas pressures are measured at different depths in order to define gradients. Measurements are made with instruments installed from land surface and from the tunnel. Above the trenches, measurements are taken at various locations within and adjacent to a trench cap. These measurements are used to determine the rates of water movement into trenches. Beneath the trenches, measurements are taken through the walls of the tunnel. Locations of measurements range from less than $1 \mathrm{~m}$ to more than $5 \mathrm{~m}$ from the tunnel in all directions. All of the different stratigraphic units in the vicinity of the tunnel are instrumented. These measurements are used to define the rate of movement of water leaving the trenches.

Water and gas samples are obtained at different distances from the waste trenches as well as at off-site control areas. This allows for the detection of changes in water and gas chemistry and the determination of the rate of constituent movement. 
Instruments used in this study are monitored at short time intervals by data loggers. This permits (1) measurement of precipitation intensities, (2) calculation of evapotranspiration, and (3) measurement of the movement of water from precipitation through the unsaturated zone. All of these phenomena can vary substantially during short time periods, hence, the need for frequent recording. Meteorological sensors are scanned every 10 seconds by a Campbell Model CR2 1 or CR7 l data logger. The logger contains a microprocessor capable of accepting analog, electrical-resistance, and electric-pulse inputs. It is also capable of performing some data processing. The 10-second readings are averaged or totalized over each hour and day. The hourly and daily values are then stored on magnetic-tape cassettes.

Output from pressure transducers installed on tensiometers are recorded on either a Campbell Model $\mathrm{CR}-5$ or $\mathrm{CR}-7 \mathrm{l}$ data logger. The frequency of recording depends upon the location of the tensiometers. Those located in the tunnel are recorded at 4-hour intervals, while those located on land surface are recorded every 5 minutes. The latter high frequency is needed in order to track the relatively quick moving wetting fronts following precipitation. Data from these recorders are also stored on tape cassette. All cassettes are replaced biweekly, and the data stored on them is transferred to computer storage.

\section{Precipitation}

Precipitation is measured with two tipping-bucket and one weighing-type rain gages. The tipping-bucket rain gage measures precipitation in $0.01-i n c h$ increments that can be accumulated in 1-minute intervals by the data-logger recorder. The weighing-type rain gage is used to obtain daily precipitation totals during the winter period. Locations of the rain gages are shown in figure 3 .

\section{Net Radiation}

Net radiation can be measured directly of in its individual components (incoming and outgoing shortwave and longwave). An individual component is measured by a radiometer that consists of a temperature compensated thermopile located between an exposed and shielded surface. The exposed surface is coated with a nonwavelength selective absorbing black lacquer while the other surface is shielded from external radiation. Wavelength specificity is achieved by placing hemispherical filters of known optical transmission $(0.3$ to 3.0 micron for shortwave and 4.0 to 50.0 micron for longwave) over the receptor. Radiant energy is converted to heat at the lacquer surface. The amount of heat, and therefore radiant energy, is determined from the difference in temperature between the two surfaces. Longwave radiometers have an additional temperature-dependent correction which is applied to compensate for radiation emitted by the detector.

1 Use of trade and brand names in this report is for identification purposes only and does not constitute endorsement by the U.S. Geological survey. 
Net radiometers operate on the same principle as individual component types. However, they differ in their broadened width of wavelength receptance and simultaneous acceptance of incoming and outgoing radiation.

Calibration is factory determined using International Pyrheliometric Scale (IPS) standards for shortwave and a low-temperature blackbody for longwave radiometers.

Net radiation is measured at the Sheffield site using both individual component and net radiometers. Incoming radiometers are mounted at $2 \mathrm{~m}$, whereas outgoing and net measurements are at $1 \mathrm{~m}$ above land surface.

\section{Soil-Heat Flux}

Conductive heat flux is measured with soil-heat flux disks. These are thin plates of known thermal conductivity containing a thermopile. The thermopile determines the difference in temperature between the top and the bottom of the disk. Using equation 5, the conductive heat flux can be computed.

Soil-heat flux disks are small so that natural movement of moisture through the soil in the vicinity of the thermopile is minimally disturbed. The disks used in this study measure approximately $3 \mathrm{~mm}$ in thickness and 28 $\mathrm{mm}$ in diameter. Their thermal conductivity is $0.33 \mathrm{~W} \mathrm{~m}^{-1}{ }^{\circ} \mathrm{C}^{-1}$. The disks are factory calibrated; however, this calbration must be adjusted to account for the difference in thermal conductivity between the disks and the soil at the site. Philip (1961) gives procedures for making such an adjustment.

In the energy-balance equation, $\mathbf{S}$ refers to the soil-heat flux at land surface. As previously stated, it is not possible to directly measure heat flux at that point. Flux plates must be installed at some depth. Between land surface and this depth, there will be a divergence of the heat flux. In order to quantify this divergence and thereby estimate the flux at the surface, it is helpful to determine the heat-flux gradient with respect to depth. Therefore, heat flux is measured at more than one depth. In addition to the heat-flux disks, soil temperatures are measured at nine different depths $(0.02$ to $1 \mathrm{~m})$ with thermocouples. The soil-temperature profile is used to quantify convective and latent heat transfers. It can also be used to compute conductive transfer as a backup to the heat-flux disks.

\section{Water-Vapor Pressure and Air Temperature}

Water-vapor pressure is determined from wet- and dry-bulb temperatures measured by a nonventilated psychrometer. This instrument consists of two thermistors, one enveloped by a wetted cotton sock. The sock serves as a wick, drawing from a reservoir of distilled water. Water evaporates from the sock and the latent heat absorbed by the vaporizing water causes the temperature of the wetted surface and the enclosed thermistor to fall below the ambient air temperature (being measured by the dry-bulb thermistor). The rate of evaporation is controlled by the vapor pressure of the surrounding air. If the vapor pressure is near the saturation point, very little evaporation and corresponding temperature depression will take place. 
The Rankin-Dupre formula (Sutton, 1953, p. 5) and the psychrometric equation (Chemical Rubber Co., 1972, p. E-39) are used to compute the saturated and actual vapor pressures, respectively:

$$
\begin{aligned}
& e_{s}=100 \cdot \exp \left[54.721-6788 /\left(T_{w}+273.16\right)-5.0016 \cdot \ln \left(T_{w}+273.16\right)\right] ; \\
& e_{a}=e_{s}-\left[B \cdot 0.00066 \cdot\left(T_{a}-T_{w}\right) \cdot\left(1+0.00115^{\circ} T_{w}\right)\right] \\
& \text { where } \quad e_{s} \text { is saturation vapor pressure, in pascals; } \\
& \quad e_{a} \text { is vapor pressure of overlying atmosphere, in pascals; } \\
& T_{a} \text { is dry-bulb temperature, in degrees Celsius; } \\
& T_{w} \text { is wet-bulb temperature, in degrees Celsius; and } \\
& \text { B is barometric pressure, in pascals. }
\end{aligned}
$$

Temperatures obtained from psychrometers at heights of $1 / 2,1$, and 2 m are used to determine the actual vapor pressure and air-temperature gradients needed for Bowen-ratio calculations. Barometric pressure was obtained for the above calculations with an aneroid barometer.

Because of freezing of the wet-bulb psychrometers, actual vapor pressure during the winter period is estimated from an electrical-resistance-type relative-humidity probe.

\section{Wind Speed and Direction}

Horizontal wind speed is measured at three elevations with 3-cup photochopper anemometers. These instruments contain a small light source and photo-Darlington sensor separated by an opaque film disc with a single window. Each rotation of the cup wheel permits the window to pass between the lamp and collector allowing a short electric pulse to be sent to a recorder. The wind velocity is obtained by applying a coefficient to the number of pulses received per unit time.

A potentiometric wind vane provides wind direction. This device transforms direction into an electrical resistance. The data logger senses this resistance and computes a vectorized wind direction and wind speed.

\section{Liquid Pressure Head}

For this project, liquid pressure heads are measured with tensiometers that are capable of measuring pressures ranging down to about $-8,500 \mathrm{~mm}$ of water. Preliminary work at the site has shown that only during late summer in the top $500 \mathrm{~mm}$ of soil are pressures less than $-8,500 \mathrm{~mm}$. 
Tensiometers are constructed by attaching a porous ceramic cup to sealed tubing that is subsequently filled with gas-free water (fig. 6). The other end of the tubing is then attached to a pressure-sensing device, such as a manometer, vacuum gage, or pressure transducer. The ceramic cup is placed in contact with soil and the pores in the cup form a continuum with the pores in the soil. Water moves through the ceramic cup in response to a pressure gradient until equilibrium is obtained. The negative pressure measured by the sensor is then converted to a soil-water tension.

Tensiometers are installed by first augering a hole that is slightly larger in diameter than the tubing, to a distance that is slightly less than the desired cup location. Next a tube with the same diameter as the porous cup is used to collect a sample at the desired location. The ceramic cup is then pushed into the hole and a tight fit is obtained. The hole is backfilled with the same material that was removed from the hole. The method of backfilling depends upon the type of material; if the material is coarse, it is lowered down the hole through a tube and compacted to its approximate natural bulk density by tamping. If the soil is fine, such as a clayey till, a slurry is made with soil and water and is pumped into the hole. The final $50 \mathrm{~mm}$ of each hole is filled with a cement-grout plug to prevent moisture and air from seeping along the access tube to the cup.

Approximately 35 tensiometers have been installed from land surface at depths from $50 \mathrm{~mm}$ to $2 \mathrm{~m}$ (figs. 7 and 8 ). More than 50 tensiometers have been installed from the tunnel. They extend in all directions, at distances from 0.1 to $5.1 \mathrm{~m}$ from the tunnel wall.

Most tensiometers used at the site are attached to differential pressure transducers which in turn are connected to a data-logger recorder. The pressure transducers measure the difference in atmospheric pressure and the pressure of the tensiometer, and output a voltage which is linearly related to the pressure difference. Three types of transducers are used, differing only by the range of pressure differences they measure ( 0 to $704 \mathrm{~mm}$ of water, 0 to $3,520 \mathrm{~mm}$, and 0 to $10,560 \mathrm{~mm})$. The accuracy of the transducers are about 1 percent of the range; hence, the smaller the range the greater the accuracy.

\section{Soil-Moisture Content}

Measurements of liquid pressure head and soil-moisture content are made in the field to better define the soil-moisture retention curve. Moisture content can be determined using one of two approaches: (1) Gravimetrically, in which a soil sample is obtained in the field, weighed, then oven dryed and weighed again (to obtain moisture content by subtraction) or (2) in-situ measurements, which include neutron moderation and gamma-ray attenuation among others. Gravimetric analysis is accurate but destructive and was not used extensively in this study. Neutron moderation and gamma-ray attenuation are both used in this study, although they have the disadvantage of requiring the use of radioactive sources. 


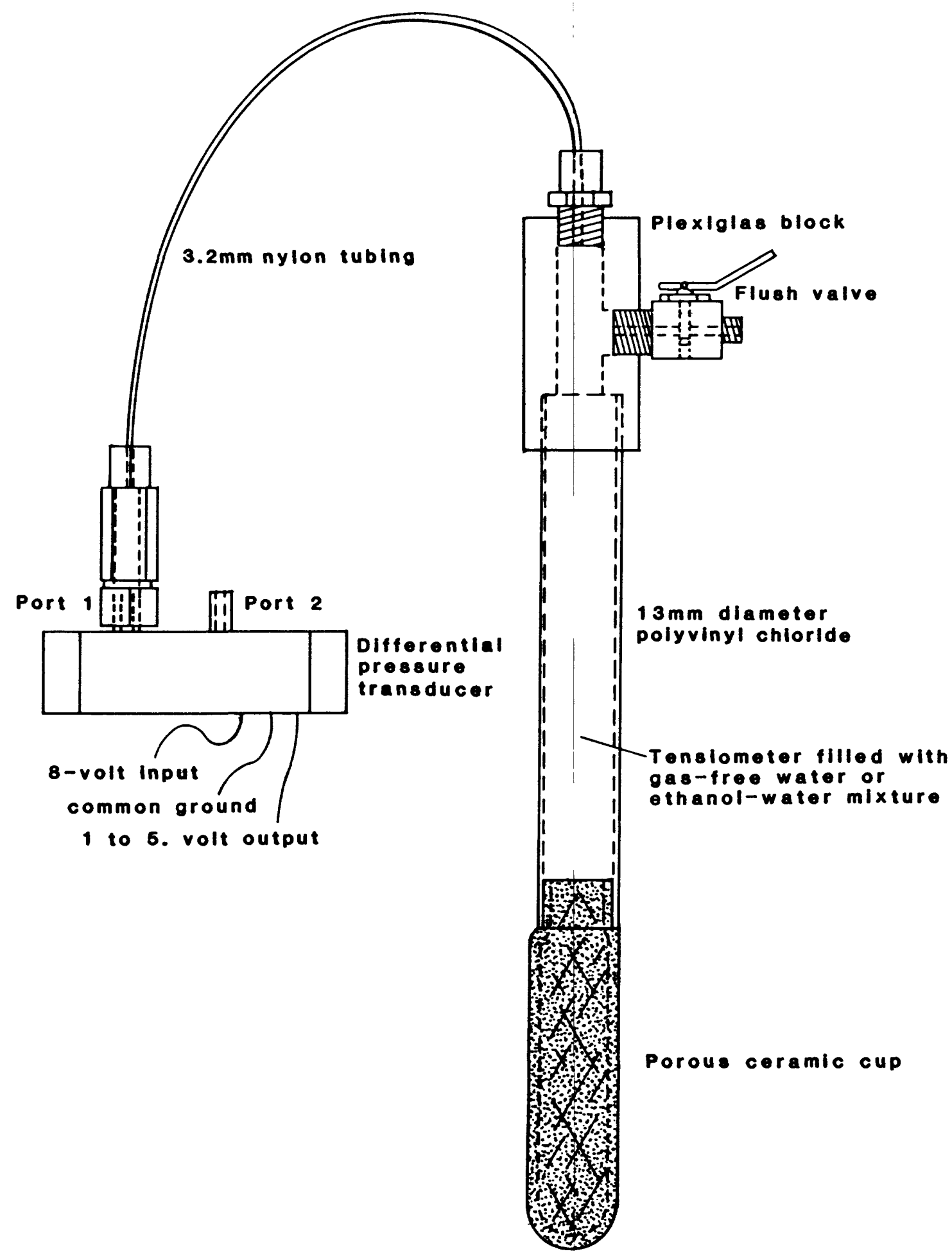

Figure 6.--Schematic diagram of soil-water tensiometer used at Sheffield site. 


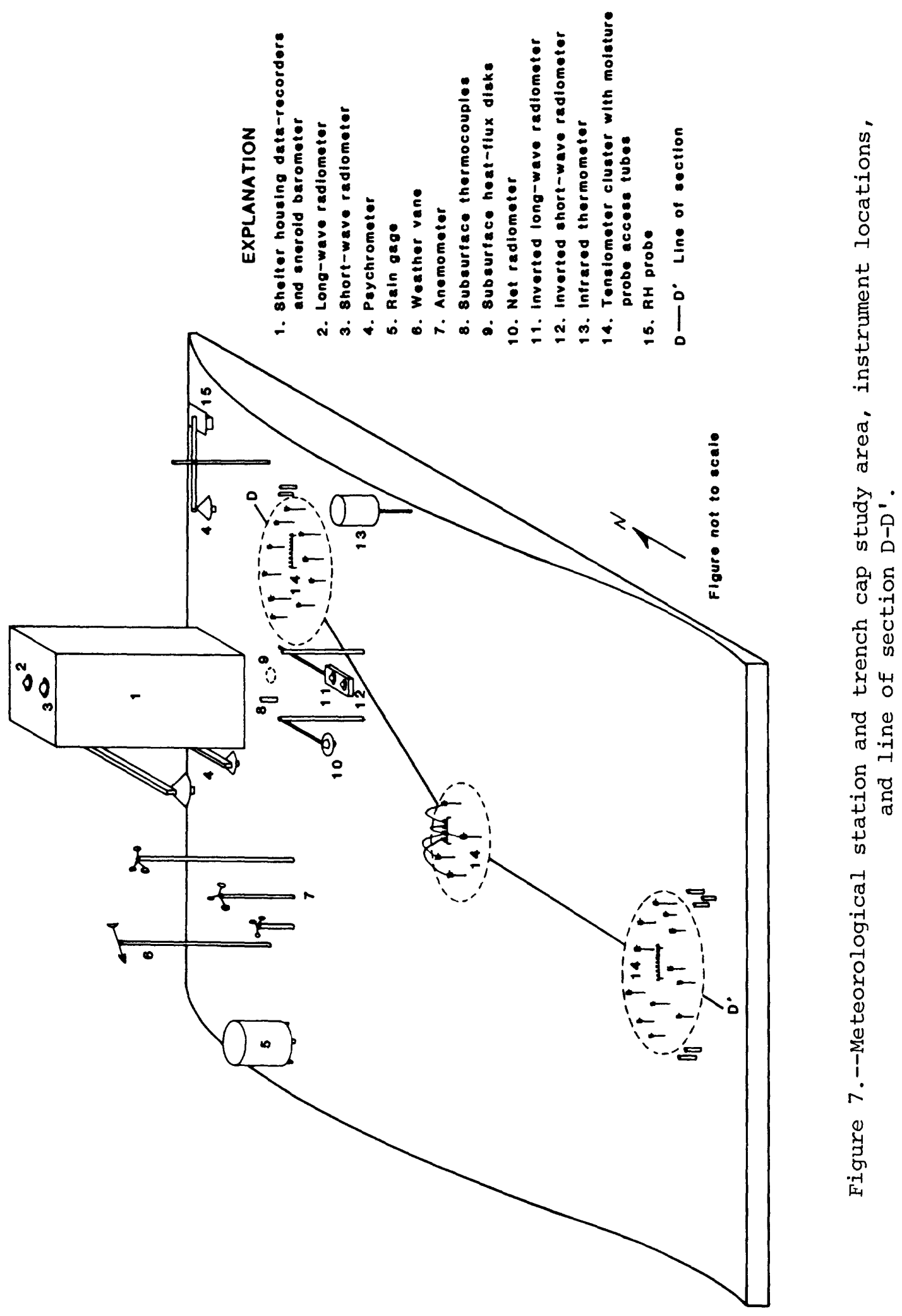




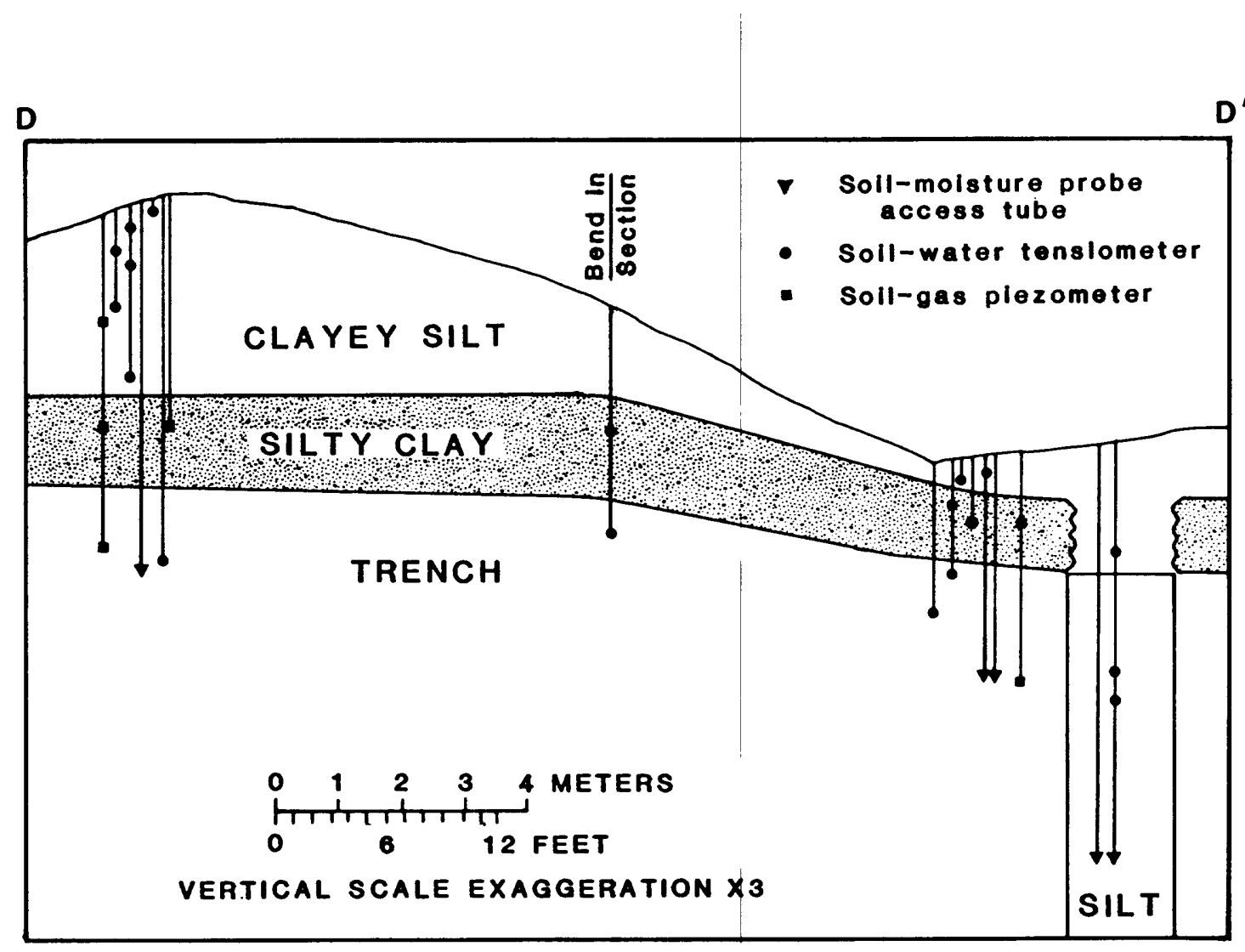

Figure 8.--Section $D-D^{\prime}$ showing lithology and instrumentation for observing subsurface moisture movement at a trench cap. 


\section{Neutron Moderation}

Soil-moisture content measurement by neutron moderation requires the use of a fast-neutron emitting radioactive source and a detector and scaler (fig. $9)$ to monitor slower moving or thermalized neutrons. The radioactive source is usually americium activitated beryllium. The source and detector are located within the same probe. The probe is lowered to different depths within the soil through aluminum access tubing. The detector is connected by an electrical cable to the scaler, which remains on land surface. Readings are taken at selected depths, usually in increments of $0.1 \mathrm{~m}$.

The neutron-moderation method relies on the fact that the fast neutrons, being emitted by the source, will collide with nearby atoms. After a number of collisions, the neutrons will be slowed enough to be registered by the detector. When the fast moving neutrons collide with atoms much larger in size, they bounce off losing little speed. However, when neutrons collide with atoms of similar size, they are slowed much more rapidly. Hydrogen atoms have the same mass as neutrons and are, therefore, the most efficient in thermalizing neutrons. A fast moving neutron can be thermalized in 20 collisions with hydrogen atoms, while several hundred collisions with nonhydrogen atoms are required (Campbell pacific Nuclear, 1980, p. 3). It is generally assumed that all thermalized neutrons received at the detector are the result of collisions with hydrogen atoms. As water is the primary source of hydrogen atoms within soils, the number of thermalized neutrons counted during a specified time period can be related to the amount of water in the soil. Depending upon the degree of saturation, readings taken with a neutron probe are influenced by hydrogen atoms as distant as 100 to $150 \mathrm{~mm}$ from the detector. Readings, therefore, produce an average soil-moisture content over the volume of soil determined by that radius of influence.

Thin-wall seamless-aluminum access tube $(508 \mathrm{~mm} 0 . \mathrm{d} . \times 1.2 \mathrm{~mm}$ wall) is used. To install access tubes, continuous soil-core samples are obtained down to the desired depth with a core barrel slightly smaller than the diameter of the tube. The lower end of the tube is plugged, and it is driven into the hole. The moisture content of the collected core is obtained gravimetrically.

Accurate calibration of the neutron probe for quantitative moisture logging is quite difficult, especially within heterogeneous sediments. Each neutron probe should be calibrated with soil of known moisture content. A calibration is required for each soil type encountered in the field.

For this study, a combination of techniques are used to develop calibration curves for the neutron gage. Immediately after installing an access tube, the neutron $\log$ is run. The readings at each depth are then compared to the moisture content at the same depth as determined from the sample cores. This produces one point on the calibration curve for each depth. Another point is obtained when the soil around the tube is fully saturated (as determined by tensiometers). Additional points may be obtained by comparison of neutron gage and gamma-ray attenuation gage results from the same access holes. 


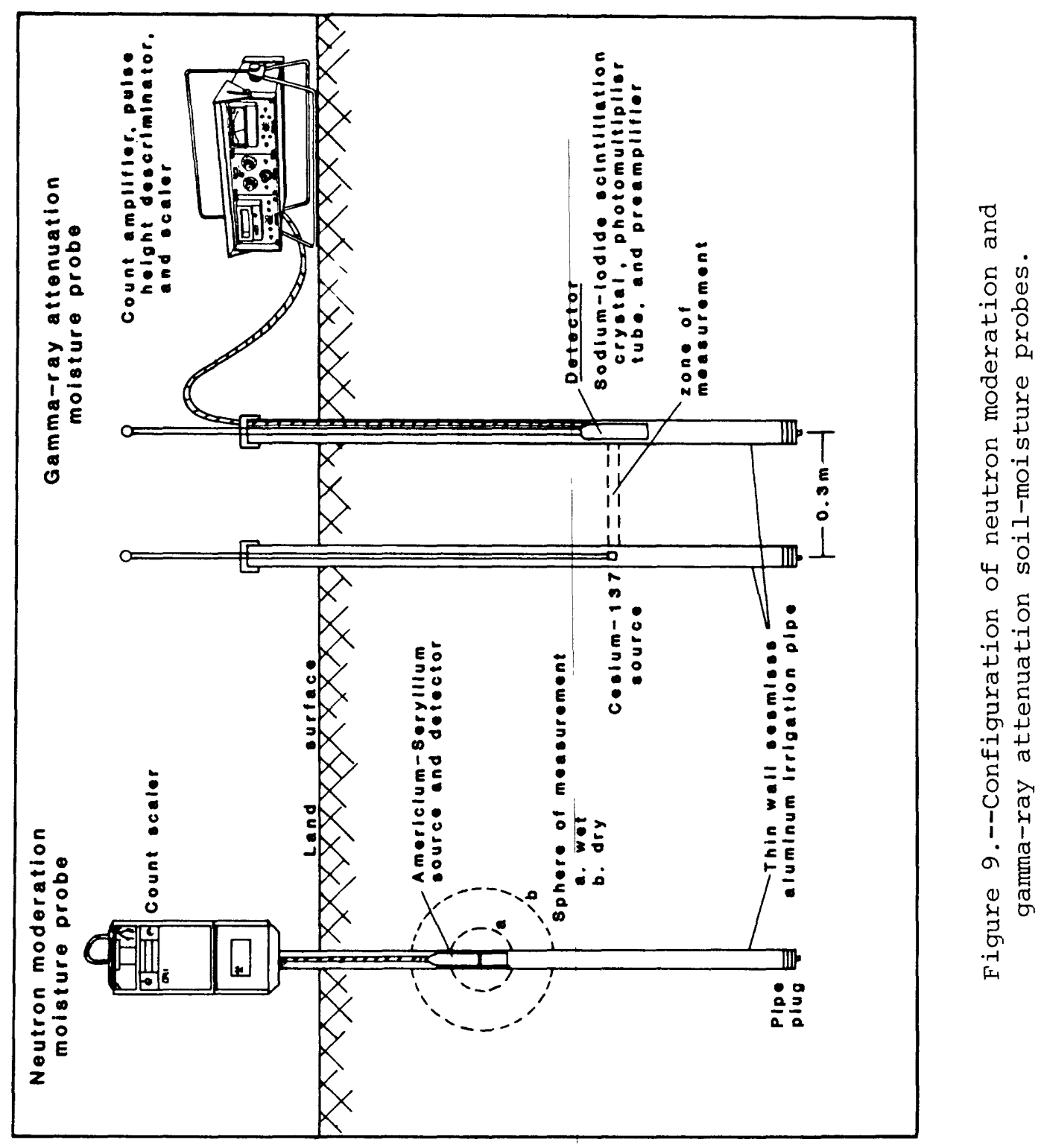


The gamma-ray attenuation method of soil-moisture determination is based upon the principle that the degree to which a beam of gamma rays is attenuated while passing through a column of soil is related to the total density of the soil (Gardner, 1965, p. 82). The denser the soil, the more gamma rays will be attenuated. The technique requires the installation of two parallel access tubes (fig. 9) within the soil. A gamma-ray emitting radioactive source (usually cesium-137) is lowered down one tube. A gamma-ray detector, in the other tube, is lowered to the same depth as the source. The detector consists of a sodium iodide scintillation crystal, photomultiplier tube, and preamplifier. It is connected to an amplifier, pulse-height descriminator, and scaler located on land surface; all of which allow for the accumulation of counts over a specified time. The number of counts per unit time is related to the number of gamma photons arriving at the detector which in turn is related to the density of the soil.

Access tubes for the gamma-ray attenuation probe are installed in the same manner as those for the neutron probe. The same type of aluminum tubing is used. For reliable measurements, the two access tubes must be parallel and $0.3 \mathrm{~m}$ apart. Construction difficulties relating to the parallel alignment of the access tubes impose a depth limitation of about $3 \mathrm{~m}$ on the gamma-ray attenuation method; below this depth neutron moderation is used.

As the gamma probe actually measures total density, it is necessary to subtract the dry density of the material (as determined from the core samples obtained during installation of access tubes) from all measurements to obtain the soil-moisture content. Determining soil moisture at future times relies on the assumption that the dry density of the materials does not change. This method permits a higher resolution than neutron moderation because the gamma rays are affected only by the soil which is directly between the source and the detector. Moisture contents can be measured in depth increments as small as $25 \mathrm{~mm}$.

Access tubes are located both on land surface (figs. 7 and 8 ) and in the tunnel adjacent to tensiometer nests. This allows moisture contents to be determined at all depths corresponding to tensiometer locations.

The gamma-attenuation probe is calibrated by the manufacturer. However, the calibration may drift over time and over temperature changes. For this reason, it is recalibrated in the field using manufacturer-supplied blocks of known density. Immediately after installation of access tubes, measurements are taken with the probe. The readings of these initial measurements are then compared with the total densities of the soil cores. A correction factor is computed for each depth at which a measurement is taken. This takes into account any voids adjacent to the access tubes and the possibility that the access tubes may not be aligned perfectly parallel. The correction factor is then used to adjust all future measurements at that location. 
Soil-gas pressures are measured relative to atmospheric pressure with a soil-gas piezometer. Soil-gas piezometers used at the site consist of 12.7mm-diameter tubes attached to 100-mm-long well screens. The screened end is installed at the desired measurement point in the same manner as tensiometers with the exception that permeable material (coarse sand) is packed around the well screen. The other end of the tube extends to land surface or into the tunnel and is attached to a very sensitive pressure transducer. Soil-gas piezometers are located adjacent to surface and tunnel tensiometer clusters.

\section{Water Sampling}

Liquid pressure heads within the unsaturated zone are negative relative to atmospheric pressure. It is necessary to counteract these tensions in order to collect pore water for chemical analyses. Suction lysimeters are used for this purpose.

The design of a suction lysimeter is similar to that of a tensiometer. A porous ceramic cup is attached to one end of a cylinder and the other end is fitted with an airtight plug. Two tubes lead through the plug into the cylinder, with one ending proximally near the plug and the other ending distally at the base of the cup. These tubes lead to the land surface, and each is terminated with a gas-tight valve.

Suction lysimeters operate on a pressure-gradient principle. A vacuum exceeding the soil-water tension is created in the lysimeter by closing the valve on the lower tube and applying suction with a vacuum pump to the upper tube. The valve on the upper tube is then closed, and the pressure gradient causes water to flow through the ceramic cup into the lysimeter. The amount of time necessary to collect a water sample varies from several hours to days depending upon the degree of saturation, hydraulic conductivity of the material sampled, surface area of the porous cup, and the magnitude of the pressure gradient.

Water samples are removed from the suction lysimeters by opening the valves on the access tubes and applying positive pressure with compressed nitrogen gas to the upper tubing. The positive pressure forces the water up the lower access tube and out into a collection vessel.

Polyvinylchloride (PVC) pipe, neoprene tubing, and teflon stopcocks are used in the construction of suction lysimeters. All materials are washed in a 10-percent hydrochloric acid ( $\mathrm{HCl}$ ) solution and rinsed repeatedly in distilled water prior to assembly. Porous ceramic cups are leached in 10-percent HCl for 24 hours. After acid leaching, the cups are thoroughly rinsed in distilled water. Materials are assembled using epoxy cement. Upon assembly, the lysimeters are again rinsed thoroughly in distilled water. More details on construction and use of suction lysimeters can be found in wood (1977) and Wilson (1980, p. 87). 
Upon completion of a borehole for lysimeter emplacement, the hole is partially backfilled with 300 mesh $(85 \mu \mathrm{m})$ silica flour. Care is taken to insure that no air spaces are created when backfilling. The lysimeters are then set firmly into the silica flour. This procedure allows for complete contact of the porous cup with the surrounding material. The parent material is used to fill the rest of the hole and a cement-grout plug is placed in the final 50 $\mathrm{mm}$. More than one lysimeter may be placed in a single borehole. The deepest lysimeter is placed in the silica flour as described, and the borehole is backfilled with parent material (about $0.3 \mathrm{~m}$ thickness) followed by a layer of bentonite clay and then a layer of cement. The hole is then backfilled with parent material until the next sampling depth is reached and the sequence is repeated. Care is taken to insure that a good seal is made around the lysimeter access tubes to insure no hydraulic communication between the lysimeters along the borehole.

A total of 28 lysimeters are being used for the study. Ten of these were installed from land surface ( $f i g .3$ ), either in or between trench caps, at various depths. Thirteen were installed beneath the trenches from the tunnel. The remaining five lysimeters were installed off-site (fig. 3) at depths ranging from 2 to $12 \mathrm{~m}$. Sampling frequency ranges from 1 to 4 weeks, depending upon season, precipitation, and constituents to be analyzed.

\section{Soil Sampling}

Cores are collected during the construction of all boreholes used for tensiometer, lysimeter, and moisture-probe access tube placement. Soil cores are collected by driving metal sampling tubes into the unconsolidated material. Sample tubes are thin-walled steel, and range in diameter from 19 to $50 \mathrm{~mm}$ and in length from 150 to $750 \mathrm{~mm}$. The size of the tube used for a particular borehole is dependent upon the geologic material and the purpose for the borehole. Tubes are driven either by a hydraulic jack or by manual hammering. In an effort to prevent moisture loss from the cores prior to laboratory analysis, all cores are left in the sampling tubes until the time of analysis. The ends of the tubes are sealed immediately with plastic cups and/or tape and then dipped in melted parafin. The sample tubes are cut longitudinally in the laboratory, and the cores are sectioned and removed.

Cores have been taken in all directions from the tunnel in order to test. for radionuclides and to better define the geology of the area. In particular, cores are taken from the top of the tunnel to the trench bottoms at several points along the length of the tunnel.

\section{Gas Sampling}

Samples of soil gas are obtained from gas piezometers at several locations as shown in figure 10 (see fig. 3 for line of section). Using peristaltic pumps, piezometers are pumped at low-flow rates $(600$ milliliters (mL) per minute) so that minimum disturbance is created on the pneumatic pressure near the piezometer screens. Following an initial evacuation period of about 20 to 30 minutes, samples are collected for analyses of constituent partial pressures and ${ }^{222} \mathrm{Rn}, \mathrm{HTO}_{(\mathrm{g})}$, and ${ }^{14} \mathrm{CO}_{2}$. 


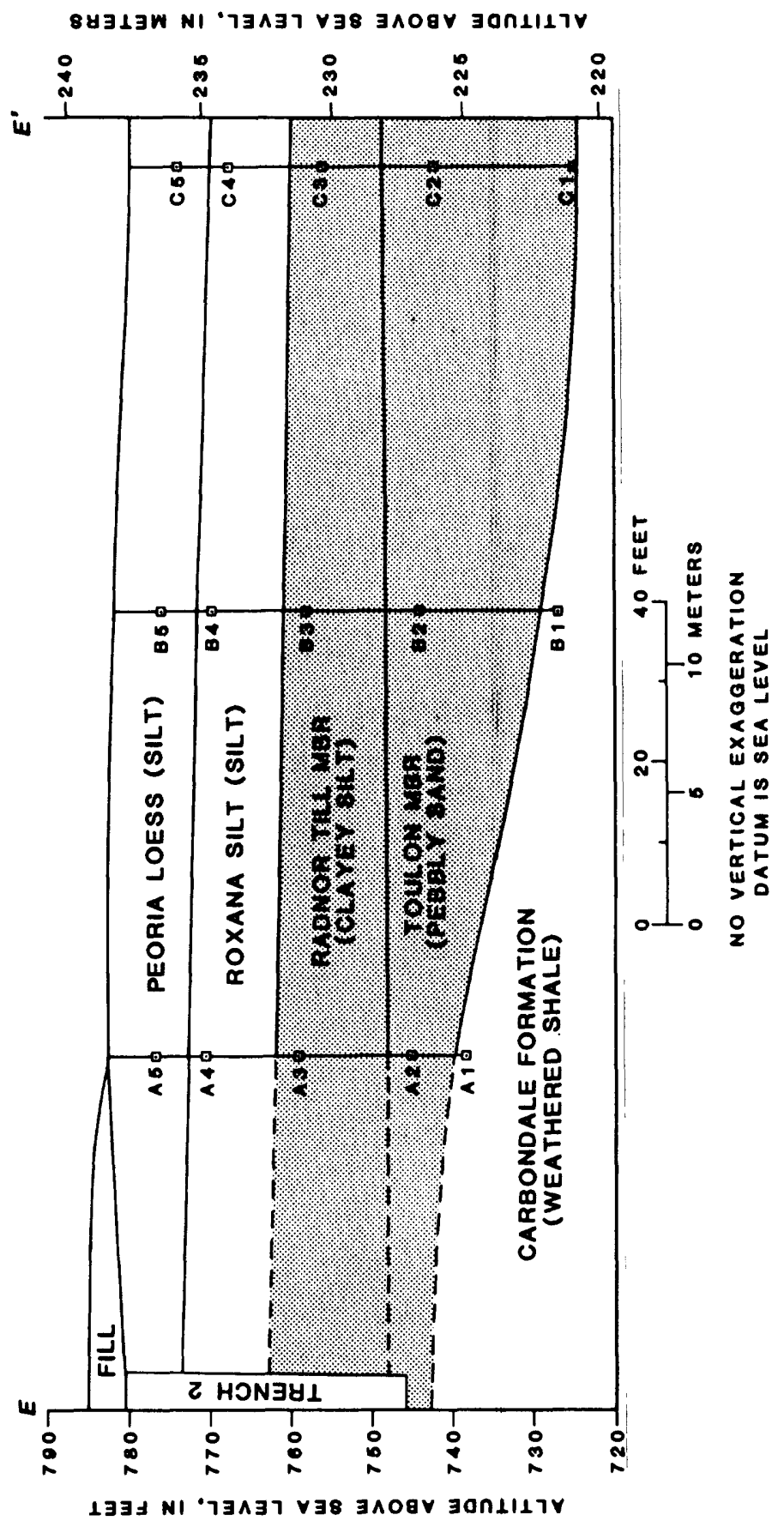

O) 
Partial pressures of nitrogen, oxygen plus argon, carbon dioxide, methane, ethane, propane, and butane are determined in samples collected in flow-through glass bulbs. At selected piezometers, samples for partial-pressure analyses are collected both before and after sampling for other constituents. Analyses of these samples tests the assumption that the composition of the sampled gas remains uniform during pumping. Radon-222 samples are collected by pumping soil gas into evacuated aerosol cannisters. Water vapor and carbon dioxide $\left(\mathrm{CO}_{2}\right)$ samples are collected simultaneously. Subsoil gas is pulled through a vacuum trap immersed in a dry ice methanol mixture (fig. 11) and then bubbled through a fritted glass plate in a $500 \mathrm{~mL}$ gas wash bottle containing $300 \mathrm{~mL}$ of carbon-free, five-molar, potassium hydroxide. Water vapor freezes out of the gas sample and is collected in the vacuum trap. Any water vapor remaining in the gas is removed by silica gel before the gas reaches the potassium hydroxide. Carbon dioxide reacts with potassium hydroxide and remains in the solution, mostly as potassium bicarbonate. Haas and others (1983) found this method of collecting $\mathrm{CO}_{2}$ to be 99 to 100 percent efficient, thus avoiding possible carbon fractionation. The sampling procedure requires about 5 to 7 hours of pumping at $600 \mathrm{~mL}$ per minute to collect about 5 liters of $\mathrm{CO}_{2}$ for carbon-14 $\left({ }^{14} \mathrm{C}\right)$ analysis.

Temperature and total pneumatic pressure are automatically recorded at selected piezometers and at the land surface.

\section{Sample Handling}

All samples (water, soil, and gas) are scanned immediately after collection for abnormally high gamma or beta emissions with a Geiger counter. Any samples with high activity must be placed in a shielded container and require special handling. If no unusual activity is detected in water samples, temperature, $\mathrm{pH}$, specific conductance, and alkalinity are determined in the field.

In the laboratory, soil cores and water are analyzed for gross alpha and beta using techniques described in Thatcher and others (1977). Tests for specific alpha and beta emitting ions and gamma spectral analyses are performed on selected samples. Tritium in water (both liquid and gas) is analyzed for each sample using liquid scintillation techniques (Thatcher and others, 1977). Soil moisture is removed from cores by freeze drying for tritium analysis. The lysimeter-collected water samples are also analyzed for major anions and cations and total organic carbon.

Selected cores are sent to laboratories for analyses for certain chemical and physical properties, such as particle-size distribution, clay mineralogy, cation exchange capacity, hydraulic conductivity, bulk density, water content, and distribution coefficients.

Partial pressure analyses of gases are performed at the U.S. Geological Survey water Quality Laboratory, Arvada, Colorado, using a gas chromatograph with a thermal conductivity detector (Robert Keck, U.S. Geological survey, written commun., 1984). Radon-222 samples are analyzed at Argonne National Laboratories by alpha scintillation counting (Lucas, 1977). 


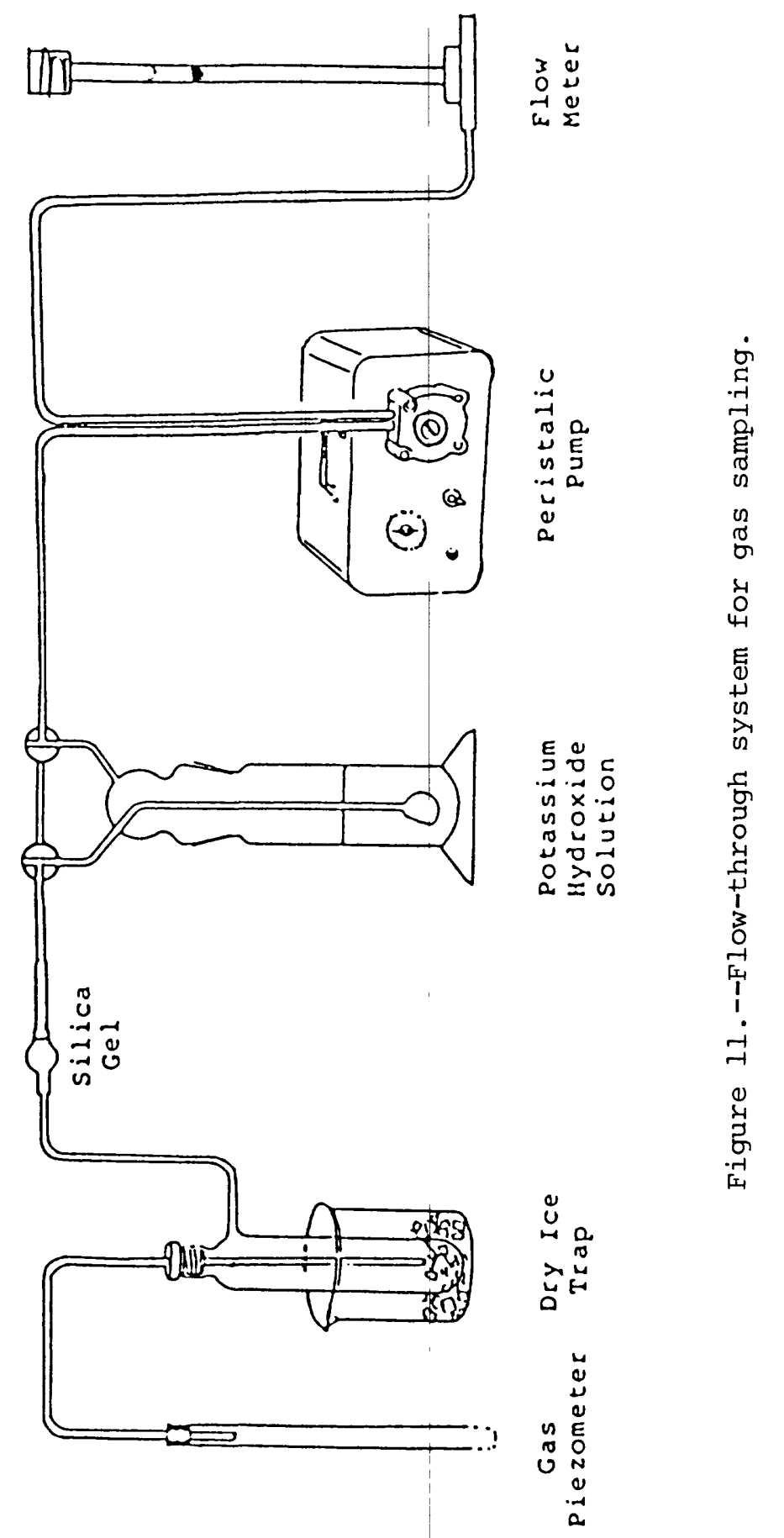


Collected $\mathrm{CO}_{2}$ from the potassium bicarbonate solution is released by acidification, isolated, and then diluted with $\mathrm{CO}_{2}$ of a known, low ${ }^{14} \mathrm{C}$ content. samples are converted to benzene and analyzed by liquid scintillation counting at the Radiocarbon Laboratory at Southern Methodist University (Herbert Haas, oral commun., 1984).

\section{SUMMARY}

A study being conducted by the U.S. Geological survey at the low-level radioactive-waste disposal site near Sheffield, Illinois, is designed to qualify and quantify the mechanisms which control the movement of water and radionuclides within the unsaturated zone. A remote data-collection system has been established to measure rainfall and parameters from which evapotranspiration, infiltration, and water movement are determined. samples of pore water, sediments, and soil gas are obtained to determine the rates of radionuclide movement from waste trenches.

Evapotranspiration is computed using energy-balance/Bowen-ratio and aerodynamic-profile methods. Direct measurements are made of precipitation, incoming and reflected shortwave radiation, incoming and outgoing longwave radiation, net radiation, air temperature and water-vapor-pressure gradients, soil temperatures and heat flux, wind speeds and direction, and barometric pressure.

The movement of infiltrated water is monitored within and adjacent to a trench cap with a series of soil-water tensiometers and gas piezometers. These instruments are fitted with pressure transducers which in turn are connected to data loggers. Neutron and gamma-ray attenuation gages are used to measure soil-moisture profiles.

A tunnel has been constructed beneath four of the waste trenches. Tensiometers and piezometers are installed through the walls of the tunnel, in all directions, to monitor water movement. Pressure transducers and data loggers are also used there.

Water samples are obtained with suction lysimeters at various locations on-site, both above and beneath waste trenches, as well as at a control site outside of the trench area. Soil-gas samples are collected from gas piezometers located at various distances from a trench. Inorganic and radiometric analyses are performed on water samples. Gas samples are analyzed for partial pressures of major constituents, Radon-222, tritiated water vapor, and carbon-14 dioxide. 
REFERENCES CITED

Arya, L. M., Farrell, D. A., and Blake, G. R., 1975, A field study of soil moisture depletion patterns in the presence of growing soybean roots: 1. Determination of hydraulic properties of the soil: Soil science Society of America Proceedings, v. 39, p. 424-430.

Bear, Jacob, 1972, Dynamics of fluids in porous media: New York, American Elsevier, $764 \mathrm{p}$.

Bouma, J., Baker, F. G., and Veneman, P. L. M., 1974, Measurement of water movement in soil pedons above the water table: University of Wisconsin - Extension Geological and Natural Fistory Survey Information Circular Number $27,114 \mathrm{p}$.

Bowen, I. S., 1926, The ratio of heat losses by conduction and by evaporation from any water surface: Physical Review, v. 27, p. 779-787.

Brooks, R. H., and Corey, A. T., 1964, Hydraulic properties of porous media: Hydrology Paper 3, Colorado State University, Fort Collins, 27 p.

Campbell, G. S., 1977, An introduction to environmental biophysics: New York, Springer-Verlag, 159 p.

Campbell Pacific Nuclear, 1980, Operator's manual 503 Hydroprobe moisture depth gauges: Pacheco, California.

Chemical Rubber Co., 1972, Handbook of chemistry and physics, 53 ed.: Chemical Rubber Co., Cleveland, Ohio.

Childs, E. C., and Collis-George, N., 1950, The permeability of porous materials: Proceedings of the Royal Society of London, series A:201, p. 392-405.

Denmead, O. T., and McIlroy, I. L., 1970, Measurement of non-potential evaporation from wheat: Agricultural Meteorology, v. 7, p. 285-302.

Fischer, J. N., 1983, Low-level radioactive-waste program of the U.S. Geological Survey--in transition, in Proceedings of the Fifth Annual Participants' Information Meeting, DOE Low-Level Waste Management Program, Denver, 1983: Idaho Falls, Idaho, U.S. Department of Energy, CONF-8308106, p. 52-61.

Foster, J. B., and Erickson, J. R., 1980, Preliminary report on the hydrogeology of a low-level radioactive-waste disposal site near Sheffield, Illinois: U.S. Geological Survey Open-File Report 79-1545, 87 p.

Foster, J. B., Erickson, J. R., and Healy, R. W., 1984, Hydrogeology of a lowlevel radioactive-waste disposal site near Sheffield, Illinois: U.S. Geological Survey Water-Resources Investigations 83-4125, 83 p. 
Foster, J. B., Garklavs, George, and Mackey, G. W., 1984, Hydrogeologic setting east of a low-level radioactive-waste disposal site near sheffield, Illinois: U.S. Geological Survey Water-Resources Investigations Report $84-4183,20$ p.

Freeze, R. A., and Cherry, J. A., 1979, Groundwater: New Jersey, PrenticeHall, 604 p.

Gardner, W. H., 1965, water content, in Black, C. A., ed., Methods in soil analyses: Agronomy No. 9, American Society of Agronomy, p. 82-125.

Gray, J. R., 1984, Runoff, sediment transport, and landform modifications near Sheffield, Illinois, in Proceedings of the Sixth Annual Participants' Information Meeting, DOE Low-Level Waste Management Program, Denver, 1984: Idaho Falls, Idaho, U. S. Department of Energy, CONF-8409115, p. 534-544.

Green, R. E., and Corey, J. C., 1971, Calculation of hydraulic conductivity: A further evaluation of some predictive methods: Soil science society of America Proceedings, v. 35, p. 3-8.

Haas, Herbert, Fisher, D. W., Thorstenson, D. C., and Weeks, E. P., 1983, ${ }^{13} \mathrm{CO}_{2}$ and ${ }^{14} \mathrm{CO}_{2}$ measurements on soil atmosphere sampled in the subsurface unsaturated zone in the western Plains of the U.S.: Radiocarbon, v. 25, no. 2 , p. 301-314.

Hillel, Daniel, 1980, Fundamentals of soil physics: New York, Academic Press, $413 \mathrm{p}$.

Hillel, Daniel, Krentos, V. D., and Stylianon, Y., 1972, Procedure and test of an internal drainage method for measuring soil hydraulic characteristics in situ: Soil Science, v. 114, p. 395-400.

Huff, F. A., 1979, Hydrometeorlogical characteristics of severe rainstorms in Illinois: Illinois Institute of Natural Resources, State water Survey Report of Investigations $90,18 \mathrm{p}$.

Jackson, R. D., Reginato, R. J., and Van Bavel, C. H. M., 1965, Comparison of measured and calculated hydraulic conductivities of unsaturated soils: Water Resources Research, v. 1., p. 375-380.

Jones, D. M. A., 1966, Variability of evapotranspiration in Illinois: Illinois Institute of Natural Resources, State Water Survey Circular 89, 13 p.

Kahle, R., and Rowlands, J., 1981, Evaluation of trench subsidence and stabilization of Sheffield low-level radioactive waste disposal facility: U.S. Regulatory Commission, NUREG/CR-2101, 177 p.

Kersten, M. S., 1949, Thermal properties of soils: Engineering Experiment Station, University of Minnesota, Bulletin 28, v. 52, no. 21, 92 p. 
Klute, A., 1972, The determination of the hydraulic conductivity and diffusivity of unsaturated soils: Soil science, v. 113, p. 264-276.

Koberg, G. E., 1964, Methods to compute long-wave radiation from the atmosphere and reflected solar radiation from a water surface: U.S. Geological Survey Professional Paper 272-F, p. 107-136.

Lucas, Henry F., Jr., 1977, in Harward, E. D., ed., Workshop for measuring radiation in and around uranium mills: Atomic Industrial Forum, washington, D.C., v. 3, no. 9, p. 69-96.

Marshall, T. J., 1958, A relation between permeability and size distribution of pores: Journal of Soil Science, v. 9, p. 1-8.

Millington, R. J., and Quirk, J. P, 1961, Permeability of porous solids: Transactions of the Faraday Society, v. 57, p. 1200, 1207.

Monteith, J. L., 1973, Principles of environmental physics: New York, American Elsevier, 241 p.

Morel-Seytoux, H. J., 1983, Infiltration affected by air, crust, ice, and various sources of heterogemetry, in Advances in Infiltration: American Society of Agricultural Engineers, p. 132-146.

Mualem, Y. A., 1976, A new model for predicting the hydraulic conductivity of unsaturated porous media: Water Resources Research, v. 12, p. 513-522.

--- 1978, Hydraulic conductivity of unsaturated porous media: generalized microscopic approach: water Resources Research, v. 14, p. 325-334.

Munn, R. E., 1966, Micrometeorology: New York, Academic Press, 245 p.

Philip, J. R., 1961, The theory of heat flux meters: Journal of Geophysical Research, v. 66, p. 571-579.

Ragab, R., Reyen, J., and Hillel, Daniel, 1981, Comparative study of numerical and laboratory methods for determining the hydraulic conductivity function of a sand: Soil Science, v. 13, p. 375-388.

Robertson, J. B., 1981, Modeling in low-level radioactive waste management from the U.S. Geological Survey perspective, in Modeling and Low-Level Waste Management: An Interagency Workshop, Denver, 1980: Oak Ridge, Tennessee, Oak Ridge National Laboratory, ORO-821, p. 21-30.

Sellers, w. D., 1965, Physical climatology: Chicago, University of Chicago Press, 272 p.

Siefken, D. L., 1982, Introduction, in Arnold, E. M., and others, eds., Symposium on unsaturated flow and transport modeling: U.S. Nuclear Regulatory Commission, NUREG/CP-0030, 351 p. 
State of Illinois, Department of Registration and Education, Division of Industrial Planning and Development, 1958, Atlas of Illinois Resources, section 1: Water Resources and Climate.

Sutton, O. B., 1953, Micrometeorology: New York, McGraw-Hi11, 333 p.

Swinbank, W. L., and Dyer, A. J., 1967, An experimental study of micrometeorology: Quarterly Journal of the Royal Meteorological Society, v. 93 , p. 494-500.

Thatcher, L. L., Janzer, V. J., and Edwards, K. W., 1977, Methods for determination of radioactive substances in water and fluvial sediments: U.S Geological Survey Techniques of Water-Resources Investigations, Book 5, Chapter A5, 95 p.

U.S. Department of Commerce, National Oceanic and Atmospheric Administration, 1939-1982, Climatological data for Illinois, annual summary: Asheville, N.C., Environmental Data and Information Service, National Climatic Center.

van Hylckama, T. E. A., 1980, Weather and evapotranspiration studies in a saltcedar thicket, Arizona: U.S. Geological Survey Professional Paper 491-F, 78 p.

Wilson, L. G., 1980, Monitoring in the vadose zone: A review of technical elements and methods: U.S. Environmental Protection Agency, EPA-600/7-80-134, $168 \mathrm{p}$.

Wood, W. W., 1977, A technique using porous ceramic cups for water sampling at any depth in the unsaturated zone: Water Resources Research, v. 9, p. 486-488. 